\title{
Application of Life Cycle Sustainability Assessment in the Construction Sector: A Systematic Literature Review
}

\author{
Jana Gerta Backes *(D) and Marzia Traverso \\ Institute of Sustainability in Civil Engineering, RWTH Aachen University, Mies-van-der-Rohe-Str. 1, \\ 52074 Aachen, Germany; marzia.traverso@inab.rwth-aachen.de \\ * Correspondence: jana.backes@inab.rwth-aachen.de
}

Citation: Backes, J.G.; Traverso, M. Application of Life Cycle

Sustainability Assessment in the Construction Sector: A Systematic Literature Review. Processes 2021, 9, 1248. https://doi.org/10.3390/ pr9071248

Academic Editors: Ying (Gina) Tang, Michele Dassisti and Shixin Liu

Received: 22 June 2021

Accepted: 16 July 2021

Published: 19 July 2021

Publisher's Note: MDPI stays neutral with regard to jurisdictional claims in published maps and institutional affiliations.

Copyright: (c) 2021 by the authors. Licensee MDPI, Basel, Switzerland. This article is an open access article distributed under the terms and conditions of the Creative Commons Attribution (CC BY) license (https:// creativecommons.org/licenses/by/ $4.0 /)$.
Abstract: This paper reviews actual sustainability assessments in the construction sector to define whether and how a Life Cycle Sustainability Assessment (LCSA) is applied and interpreted in this sector today. This industry has large shares in global energy (33\%), raw material consumption (40\%) and solid waste generation (40\%). Simultaneously, it drives the economy and provides jobs. The LCSA is a method to identify environmental, social and economic impacts of products/services along their life cycles. The results of this study showed a mismatch between sectoral emissions and the number of LCSA-based impact evaluations. It was found that only $11 \%$ of papers reviewed assessed all three sustainability pillars. The economic and especially the social pillars were partly neglected. In Life Cycle Assessments (LCAs), 100\% made use of Global Warming Potential (GWP) but only $30 \%$ assessed more than five indicators in total. In Life Cycle Costing (LCC), there were a variety of costs assessed. Depreciation and lifetime were mainly neglected. We found that $42 \%$ made use of Net Present Value (NPV), while over 50\% assessed individual indicators. For the Social Life Cycle Assessment (S-LCA), the focus was on the production stage; even the system boundaries were defined as cradle-to-use and -grave. Future approaches are relevant but there is no need to innovate: a proposal for a LCSA approach is made.

Keywords: life cycle sustainability assessment; systematic review; construction; building; optimization

\section{Introduction}

Sustainability is becoming increasingly important for actual and future generations and an essential part of today's decisions in all sectors [1]. Late in 2019, the European Commission (EC) introduced the European Green Deal to tackle climate and environmental crises simultaneously. The recommendations in the EU masterplan for energy-intensive industries (such as the construction industry) were to make use of Life Cycle Assessments (LCAs) to measure the emissions of products and materials [2]. At an international level, the United Nations (UN) adopted a 10-Year Framework of Programmes on Sustainable Consumption and Production Patterns (10YFP) in 2012. One out of the five areas in the program dealt with sustainable buildings and construction approaches, in which the importance of sustainable social housing and energy, along with resource efficiency throughout the supply chain, were clearly mentioned [3]. Buildings are often considered an important and integrated part of sustainable development because of their crucial role in society, the economy and the environment [4]:

- The construction industry is responsible for about $10 \%$ of the global Gross Domestic Product (GDP) and employs 100 million people [5].

- It consumes great amounts of resources: 33\% of the global energy consumption is used by the construction sector, $40 \%$ of the raw material consumption belongs to it and the construction sector is contributing to $40 \%$ of the global solid waste generation [6,7].

- There is a high demand for concrete production, due to which the $\mathrm{CO}_{2}$ emissions of the construction industry are responsible for about $7 \%$ of the global emissions, similar to the iron and steel industries [8-10]. 
- Material extraction and manufacturing account for about $90 \%$ of the total environmental impact of a residential building, while resource extraction and manufacturing contribute about $60 \%$ of the construction costs [5].

- Continuing with business as usual in the construction sector will require a doubling in raw material extraction by 2050 [10].

Decision-makers in this sector, therefore, have a great responsibility: Effective sustainable product development starts at an early stage of a product's life cycle [11], which necessitates the Life Cycle Sustainability Assessment (LCSA) to provide a valuable support [12]. The LCSA is a life cycle-based assessment of products and services including the three pillars of sustainability: environmental, social and economic [13,14]. The results of the LCSA can be used to compare different products or contribute to sustainable decision making [15].

The aim of the structured literature review in this study was to define whether and how the LCSA is applied and interpreted in the construction sector today. Step 1 (Figure 1) of the review starts with problem definition and the initial research question: Does the LCSA find applications in the construction sector, and if so, how and to what extent?

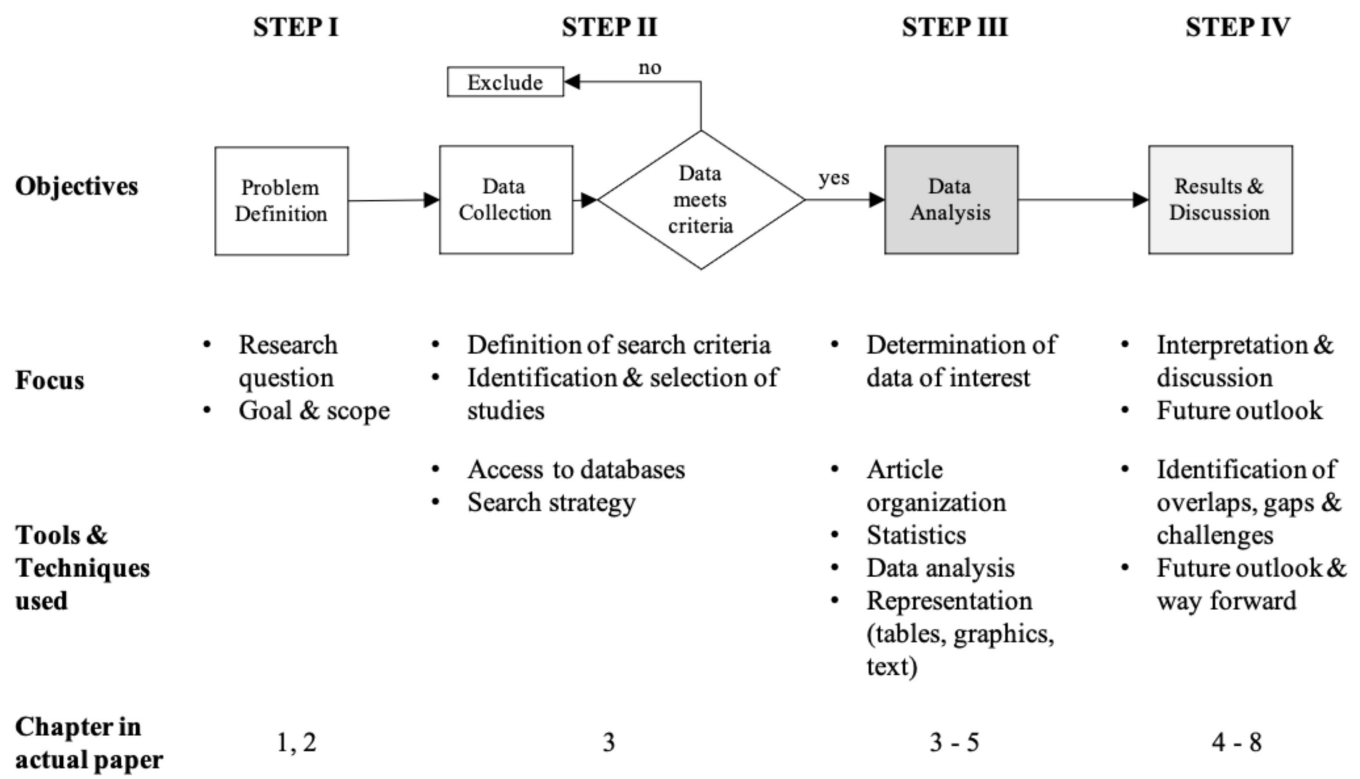

Figure 1. Article structure.

Five more questions that arose from the initial one, to specify further, were:

1. Do LCSA studies follow the approach of Finkbeiner et al. (2010) and Kloepffer (2008)?

2. How many and which indicators are applied and reported per pillar (LCA, Social Life Cycle Assessment (S-LCA), Life Cycle Costing (LCC))?

3. Which results are depicted and how are they interpreted?

4. Are any challenges evident in the studies, and what are they?

5. What anchors the LCSA and the construction sector? How could implementation strategies further be improved?

The study consisted of four steps (Figure 1) according to Cooper (1982) and Fink (2019) [16,17]. In step 1, the initial research question was defined, bibliographic databases were selected and search terms were chosen. Step 2 dealt with the practical screening, leading to the core of the article in step 3; by applying a systematic literature review, quantitative-qualitative content analysis methods were used, with the methodological screening focusing on data from relevant studies. A review protocol and a deductive coding scheme for content analysis were designed, steadily developed and used for analysis. Based on this analysis, in step 4, data were interpreted and discussed. Statistics were mapped and overlaps, gaps and challenges were identified. 


\section{Life Cycle Sustainability Assessment}

The LCSA is intended to enable products and services to be evaluated over their life cycle, considering the three dimensions of sustainability. The approach of combining all three levels of sustainability goes back to the 'Produktlinienanalyse' (English translation: Product Line Analysis) of the German Oeko-Institut [18]. Derived from this, the widely-accepted Triple Bottom Line (TBL) approach was developed, which Kloepffer and Finkbeiner translated into a first definition of the LCSA in 2008 and 2010 [13,14]. It is a framework for sustainability assessment of both positive and negative impacts, whereby the social pillar, in particular, can have positive influence on the overall sustainability assessment [19-21]. In addition, the LCSA extends the scope of the analysis from mostly product-related questions (used for the LCA) to sector-related questions [22]. The initial LCSA framework $[13,14]$, which is well-accepted and based on the three-dimensional sustainability concept, is often described by the following formal Equation (1):

$$
\mathrm{LCSA}=\mathrm{LCA}+\mathrm{LCC}+\mathrm{S}-\mathrm{LCA}
$$

where the LCA is the environmental assessment of a product's life cycle [23], LCC (as Life Cycle Costing) is the evaluation of costs and revenues of a product life cycle [24] and S-LCA is the Social Life Cycle Assessment, which evaluates positive and negative social impacts $[20,25]$. Equation (1) is based on three separate life cycle-based evaluations for each sustainability dimension. The formal LCSA equation describes the idea of implementing the three techniques in a way that is complementary and contemporary to the same functional unit (FU) and equivalent system boundaries. The LCSA interpretation phase does not require any weighting between the three pillars. The three assessments are equal and poor performance of one pillar cannot be compensated by better performance of another pillar $[13,14]$. It is also not recommended to aggregate the results due to the consequent risk of missing transparency in the LCSA's infancy stage [5]; such a misleading scenario is shown by Equation (1). Besides the LCSA application option introduced by Kloepffer (2008) and Finkbeiner et al. (2010) [13,14] (Equation (1)), a second option for LCSA application has been developed by Kloepffer (2008) [14], Guinée et al. (2011) [26] and Heijungs, Huppes and Guinée (2010) [27]. Option 2 (expressed in Equation (2)) differs from Option 1 (Equation, (1)) by ideally being based on a single product system inventory (instead of three), called the Life Cycle Inventory [23]. Connected and intertwined with this is the evaluation of many impact categories related to the three sustainability dimensions, which is covered by an integrated Life Cycle Impact Assessment (LCIA) [23,26]. Kloepffer (2008) [14] named this Option 2 'LCA new'. Guinée et al. (2011) and Heijungs et al. $(2010)[26,27]$ named Option 2 the 'integrated sustainability assessment with life cycle perspective'. Both naming schemes pursue the same goal of a single product system inventory.

$$
\begin{aligned}
& \text { LCSA }={ }^{\prime L C A ~ n e w ' ~} \leftrightarrow \\
& \text { LCSA }=\text { 'integrated sustainability assessment with life cycle perpective' }
\end{aligned}
$$

The advantage of the LCSA, for both options (Equations (1) and (2)), is the transparency and the identification of potential trade-offs (fictitious examples: lower emissions vs. higher costs; fair wages vs. higher emissions) between the three sustainability pillars, each affected by different levels of maturity and different target functions of each sustainability dimension [28]. Some approaches are available to support the understanding and interpretation of the LCSA for non-experts and decision makers: Scales and figures help address the levels of indicators used in the LCSA and the individual pillars [13]. Examples to be named are: the Life Cycle Sustainability Triangle (LCST) [13], the Life Cycle Sustainability Dashboard (LCSD) [29], the Sustainability Crowns [30] and the Tiered Approach [28].

The LCSA differs from approaches such as the MSCI Environmental, Social and Governance (MSCI ESG) [31], Refinitiv [32] or EcoPortal [33] in that the LCSA is applied 
to products by focusing on the complete product life cycle and not by weighting the individual pillars. The MSCI ESG, for example, is more at a corporate level and is used to compare companies and their exposure to industry-specific risks based on business activities, location and how risks are managed. The goal is to identify low-risk business investment opportunities and manage enterprise risks [31-33], not to assess negative and positive impacts generated along a product life cycle as the LCSA does independently by companies and financial strategies.

\subsection{Individual Assessments and Construction Norms (Step I)}

The Life Cycle Assessment (as part of the LCSA) offers an approach for assessing processes and systems and quantifying their potential environmental impacts. It is a widely applied method, and furthermore, the only non-sector-specific standardized environmental assessment method concerning ISO 14040/44. The four phases of the LCA are (1) Goal and Scope definition, (2) Life Cycle Inventory Analysis (LCI), (3) Life Cycle Impact Assessment (LCIA) and (4) Interpretation [14,23]. In the LCA, energy and material flows (as inputs) and associated waste flows and emissions (as outputs) are assessed, as well as their effect on the ecosystem and human health. Among the assessment methods within the LCSA, the LCA is considered the most developed and completely standardized [15]. LCI data can be obtained from the literature, from internal company data or from databases. Several databases, such as Ecoinvent or $\mathrm{GaBi}$, and various software solutions, such as $\mathrm{GaBi}$, SimaPro, Umberto or OpenLCA, currently simplify data acquisition and processing. Further, platforms such as, e.g., the EcoPlatform [34] or Ökobaudat [35] help collect environmental data to support mainstreaming LCAs for building and infrastructure projects by providing data. The Life Cycle Impact Assessment (LCIA), the third phase of the LCA, consists of few other steps, the classification and characterization of which are mandatory according to ISO 14040 (2006). For classification, all emissions-for example, greenhouse gas emissions-are assigned to the so-called Global Warming Potential (GWP) impact assessment category. For characterization, each Life Cycle Inventory datum is translated into an impact category by characterization factors. There are a number of competing, selfcontained catalogs of impact categories and indicators. The best-known LCIA methods are CML, Eco-indicator99, ILCD, IMPACT2002+, ReCiPe and TRACI 2.1. The CML method includes so-called problem-oriented mean indicators along impact categories, such as Global Warming/Climate Change (GWP) [36]. Damage-oriented approaches to the LCIA, such as Eco-indicator99, use so-called endpoint indicators, namely, Human Health, Resource Depletion and Ecosystem Quality. In the construction sector, additionally, ISO 14040/44, ISO 15686-5 [37] and DIN EN 15804 [38] are well-known and established, following similar life-time stages.

The LCC can be designated as the economic counterpart of the LCA [14]. It is a methodology encompassing and assessing all costs related to a product arising in all life cycle stages from cradle-to-grave [39], favorable as not only purchase prices are considered, but also costs over the entire life cycle [40,41]. A further objective of the LCC is the identification of cost drivers and trade-offs in the life cycle of a product $[24,42,43]$. A code of practice for the LCC complementary to the LCA was developed by the Society of Environmental Toxicology and Chemistry (SETAC) in 2008 [44]. In the construction sector, the LCC has been partly standardized for the assessment of buildings with ISO 15686-5 [37]. In general, the LCC follows the framework of ISO 14040/44. Defining objectives and a scope is analogous to the LCA. Both assessments (LCA and LCC) focus on an equivalent definition of the product system. Unlike the LCA, there is no comparable phase of impact assessment in the LCC because all inventory data comprise a single unit of measurement: currency. Consequently, there is no need to characterize inventory data. A challenging aspect of the LCC is the proposed coverage of all costs over the entire life cycle, with costs borne by different actors [24,44]. Hunkeler et al. (2008) [44] distinguished three types of LCC:

- conventional LCC (type I), 
- environmental LCC (type II),

- societal LCC (type III).

Conventional LCC (type I) adds up direct costs (and revenues), usually performed from a manufacturer or customer perspective for planning and comparing investment alternatives. Both type II and III additionally capture externalities based on different system boundaries. Environmental LCC includes external effects with environmental relevance. These effects are either captured and integrated as external costs or assessed using a parallel LCA. The most complex form (societal LCC) also includes all external social costs, such as negative user costs or positive consequences for society. Type II and III can be aligned with LCA and S-LCA to avoid double counting effects. Both approaches (types II and III) can also be used independently to monetize externalities [44].

The Social Life Cycle Assessment (S-LCA) represents a methodology to assess the social impacts of products and services along their entire life cycle. It can be performed by itself or in combination with the LCA and/or LCC [13]. The S-LCA is based on the LCA framework and was initially conceived as a social complement to the LCA [45]. In 2009, the United Nations Environment Programme (UNEP) and the Society of Environmental Toxicology and Chemistry (SETAC) published the first guidance document on conducting the S-LCA for products [20]. In December 2020, a revised version of the guidelines were published to take into consideration the different developments that have occurred in the last ten years [25,46]. The S-LCA considers the same functional unit and equivalent system boundaries as the other two assessment methods [20,21,25]. In this respect, the S-LCA closely follows the LCA and the four steps of the LCA. The methodological differences between the S-LCA and LCA can be described as follows: Initially, relevant stakeholders (categories) must be defined and selected. The overall results of the S-LCA strongly depend on this selection. Furthermore, resulting positive and negative impacts strongly depend on local (geographical) conditions and organizational behavior in the company-not only on production processes (as is the case for the LCA). As a result, the social impacts of two technologically identical production processes for different countries or regions may be completely different. During the LCIA, impact categories (subcategories) are defined by suitable protection areas $[20,25]$.

For buildings, especially, environmentally-related rating systems exist and often consider more than just the environmental dimensions. In Germany, approximately 2100 buildings were certified in 2019 , of which about $64 \%$ have been certified with DGNB (Deutsches Gütesiegel für Nachhaltiges Bauen-DGNB) and about $18 \%$ with either LEED (Leadership in Energy and Environmental Design) or BREEAM (Building Research Establishment Environmental Assessment Methodology) [47]. As there is no legal obligation at a federal level to assess the sustainability of buildings, even if there are country-specific efforts such as BBSR [48] or INIES [49], or international associations such as InData [50] that are driving efforts on LCA, Environmental Product Declarations [51] and Product Environmental Footprints [52] in the construction sector, this is done on a voluntary basis (Figure 2).

The Building Research Establishment Environmental Assessment Methodology (BREEAM) was developed and launched by the Building Research Establishment Ltd. in 1990. The environmental impact assessment is not a minimum standard in BREEAM, nor is the LCC. Furthermore, BREEAM certification does not consider the social impacts over the entire life cycle of a building. Visual, thermal and acoustic comfort as well as indoor air quality are mainly the focuses [53]. Those impacts could be considered in the social dimensions. However, they take into consideration only the impact in the use phase and the user as the stakeholder, rather than those along the supply chain, neglecting other stakeholder categories such as workers and the local community, which are quite relevant in the S-LCA [25] (Figure 2, missing connection). 


\begin{tabular}{|c||l||l|l|l|}
\hline LCA & $\begin{array}{l}\text { detailed approach for assessing } \\
\text { processes and systems; } \\
\text { quantifying potential } \\
\text { environmental impacts }\end{array}$ & $\begin{array}{l}\text { ISO } \\
14040 /\end{array}$ \\
\hline LCC & $\begin{array}{l}\text { assessing all costs related to a } \\
\text { product arising in all life cycle } \\
\text { stages from cradle-to-grave }\end{array}$ & $\begin{array}{l}\text { SETAC } \\
2008\end{array}$ & Dartly making use of LCA and LCC \\
\hline S-LCA & $\begin{array}{l}\text { assesses the social impacts of } \\
\text { products and services along } \\
\text { their life cycle }\end{array}$ & $\begin{array}{l}\text { UNEP } \\
2009 /\end{array}$ & $\begin{array}{l}\text { Denvironmental, economic and social } \\
\text { impact assessments are no required } \\
\text { standards }\end{array}$ & BREEAM \\
\hline
\end{tabular}

LCSA

sustainability assessments

exemplary rating systems in construction

Figure 2. Sustainability assessments and rating systems.

In 1998, the Leadership in Energy and Environmental Design (LEED) rating system was developed by the US Green Building Council (USGBC). The LEED certificate has a strong focus on ecological aspects; nevertheless, the LCA is not required to obtain certification (Figure 2). It is, therefore, up to the user to decide whether to carry out an LCA for their project. The LCC and S-LCA are not considered any further. The calculation of the building's energy costs is mandatory, and the social focus is on the building's user and their comfort requirements. These include visual and acoustic aspects, as well as indoor air quality [54] (Figure 2). In 2007, the German Sustainable Building Council developed the certification system named 'Deutsches Gütesiegel für Nachhaltiges Bauen-DGNB'. The environmental quality of the building is assessed, among other things, by carrying out an LCA (Figure 2). The system boundaries of the LCA do not cover all life cycle phases of a building according to DIN EN 15978-2012 (CEN/TC 350), with the building construction phase completely omitted. Preparatory measures such as soil excavation and the associated processes are also not considered. In the use phase, the processes for repair, maintenance, modernization and water consumption in operation are not included either. The economic quality of the building to be assessed is evaluated with the help of the LCC, according to ISO 15686-5 (Figure 2). The social dimension is covered by the use phase and the associated comfort requirements and health effects on the user. Minimum requirements are set for thermal, visual and acoustic comfort as well as indoor air quality. The consideration of social impacts that go beyond the use phase takes place through the category of 'Responsible Resource Extraction', which calls for social impacts to be made transparent through the value chain and for processing to meet social standards [55] (Figure 2). All three rating systems have an important role in the construction sector [56]; however, Figure 2 clearly shows that there is little to no correlation between rating systems in the construction sector and the general LCSA or the individual assessments.

These findings led to Step 1 (Figure 1) of the actual review, i.e., problem definition and the respective research question: Does the LCSA find applications in the construction sector, and if so, how and to what extent?

\section{Methodology (Step 2)}

Step 2: Data collection and selection of relevant criteria: As common tools in systematic literature reviews, the search engines Scopus Database and Web of Science were used for the practical screening. Scopus and Web of Science are known for their large quantities of peer-reviewed, reliable and high-quality literature [57]. The duplicity of articles in the databases was considered to represent a high degree of acceptance by the scientific community. Only articles in the English language were considered. A time limitation was made in all search engines covering the years 2010 to the beginning of 2021. The LCSA in its current form was defined for the first time between 2008 and 2010 [13,14]. It can be assumed that hardly any studies on the LCSA were conducted before 2010. The analysis took place in the first half of 2021. The search strategy was set up as follows (Figure 3): 


\begin{tabular}{|c|c|c|}
\hline \multicolumn{2}{|c|}{ Search engines: Scopus, Web of Science } & \multirow{2}{*}{$\begin{array}{l}\text { Published } \\
2010-2021 \\
\text { in English }\end{array}$} \\
\hline \multicolumn{2}{|c|}{ Search terms: 'Life Cycle Sustainability Assessment', 'LCSA', 'LCA AND LCC AND S-LCA' } & \\
\hline 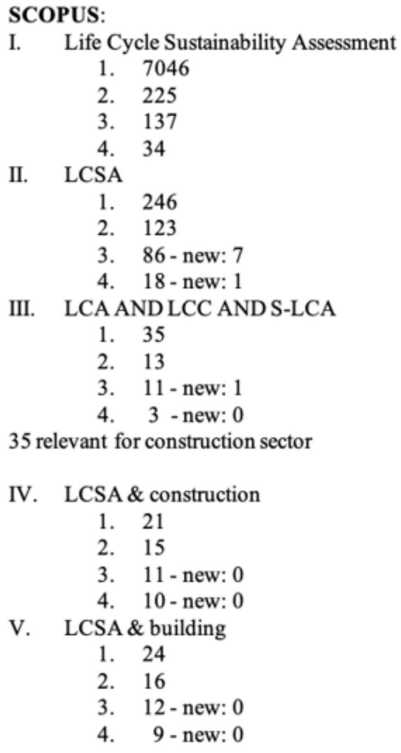 & 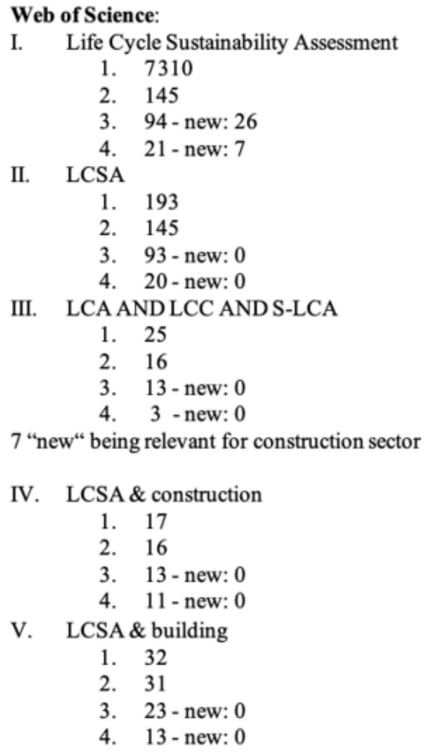 & $\begin{array}{ll}\text { 1. } & \text { Article title, } \\
\text { Abstract \& } \\
\text { Key Words/ } \\
\text { Topic } \\
\text { 2. } & \text { Limit to: } \\
& \text { LCSA } \\
\text { 3. } & \text { LCSA } \\
\text { content } \\
\text { 4. } & \text { Relevant for } \\
\text { construction } \\
\text { sector from } \\
\text { (1.) }\end{array}$ \\
\hline $\begin{array}{l}\text { Number of individual LCSA } \\
\text { Number of LCSA studies re }\end{array}$ & $\begin{array}{l}\text { es w/o double counting: } 171 \text { (3. Step) } \\
\text { to construction/building: } \mathbf{4 2} \text { (4. Step) }\end{array}$ & \\
\hline
\end{tabular}

Figure 3. Search strategy.

As shown in Figure 3, four steps were taken for every search term in each database. The search strategy can be explained by the example of the search term 'Life Cycle Sustainability Assessment', applied in the SCOPUS database: The search term was entered into the database, applying the limitations of publication year and language. The search was performed for Article title, Abstract and Key Words or Topic (1). In the example mentioned, this strategy led to 7046 search hits. To refine and focus the search, a further limitation was used for the search term 'LCSA' or 'Life Cycle Sustainability Assessment' (2). For the defined example, this limited the number of hits to 225 publications. This number of hits was examined for the actual content of the LCSA by quick analysis (reading through the papers' abstracts, introductions and conclusions) led by the authors (3). Up to this point, the review included studies that named themselves as LCSA studies in the title, but for many, the abstract, introduction and conclusion showed the focus to be on either the LCA, $\mathrm{CO}_{2}$ footprint or energy demand, and not on the LCSA. By applying this criterion, further publications could be excluded. A reduced number of 137 LCSA-relevant publications in our example remained. In order to finally focus on the construction sector, another content analysis was performed (4). This final focus applied, for instance, to the range of houses, walls, ceilings, bridges, roads, sewage systems and windows, leading to a final hit count of 34 peer-reviewed journal publications. The four-step search strategy was used for both other defined search terms: 'LCSA' and 'LCA AND LCC AND S-LCA'. To make sure the building sector was actually covered, the search terms 'LCSA OR Life Cycle Sustainability Assessment AND construction' and 'LCSA OR Life Cycle Sustainability Assessment AND building' were used additionally. This addition did not lead to any further results; only duplicates occurred in this search, as shown in Figure 3 by the representation 'new: 0'.

Finally, a total number of 171 articles was found with 42 relevant articles. Articles on general LCSA, LCSA explanations and progress, (renewable) energy, chemicals, transport, biomass, waste management without reference to the construction sector, agriculture/nutrition/food and/or geotechnology were excluded from the detailed strategic literature review. In the methodological screening (step 3 (Data Analysis)), we focused on data from the relevant studies. The text screening led to a deductive coding scheme, which was continuously developed. With each additional article added, the coding scheme was 
iteratively and steadily developed. For example, an initial LCSA article in the LCA specified Global Warming Potential and Primary Energy Demand indicators. The second article continued to specify Acidification Potential and Eutrophication Potential; consequently, these two additional indicators were included in the coding scheme. Statistical statements about publication year, author origin, journal and type of publication were compiled. Further, analyzed products, system boundaries, $\mathrm{FU}$ and the individual assessment techniques (LCA, LCC and S-LCA) including reported indicators (e.g., GWP, Acidification Potential (AP), Eutrophication Potential (EP), etc., used) were analyzed.

\section{Reviews (Step 3)}

Step 3 represents the main aspect of actual study, the data analysis: In total, 42 papers were selected as relevant and analyzed in detail. 14 papers out of the selected 42 articles constituted a review in the construction and sustainability sector; it was noticeable that none of the reviews was older than five years (Table A3 in Appendix A). Despite there being 14 review papers, none of the authors had yet considered the application and interpretation of the LCSA in the construction sector. The necessity for the current review became more evident after considering the reviews that had already been published:

- No review focused on studies published between 2010 and today,

- No review used the actual search terms we used, with 'LCSA' and 'Life Cycle Sustainability Assessment' rarely used [58-70],

- The number of papers reviewed and considered as relevant varied between 9 and 71,

- Few studies defined the search strategy, databases used or number of reviewed papers $[58,60,65,68,70]$,

- No interpretation or visualization variants were discussed,

- Few reviews focused on selected indicators (Table A3).

\section{Results}

A total of 171 publications were identified addressing Life Cycle Sustainability Assessment according to the title, abstract and key words. The results of the detailed literature review are presented below, focusing on 42 studies relevant to the construction sector.

\subsection{Statistics (Steps 3 and 4 )}

Although the focus was on studies relevant to the construction sector, a comparative look at the statistics of all 171 articles is provided. An increase in the number of publications becomes apparent, with a peak in 2020 at 35 publications (Figure 4). This trend can possibly be explained by the fact that the topic of sustainability, in general, has gained significant relevance over the past five years. In 2015, at the Paris climate conference (COP21), 195 participating countries came to a climate agreement that would limit global warming to well below $2{ }^{\circ} \mathrm{C}$, preferably $1.5^{\circ} \mathrm{C}$ compared to pre-industrial levels [71]. Also in this year, the Sustainable Development Goals were set by the United Nations General Assembly [72].

In the following years, there were repeated calls in various journals for special issues on the LCSA or on sustainable building; for example, in 2016 and 2017 in the 'Journal of Industrial Ecology' and in 'Sustainability' [73,74]. A total of 9 out of 171 papers are book chapters [75]. The remaining 154 studies are journal and conference articles. Of the 171 publications, $18 \%$ (28 studies) were published through the 'International Journal of Life Cycle Assessment' ('IntJLCA'), followed by 14\% (21 studies) through the 'Journal of Cleaner Production' ('J.Clean.Prod.') and 8\% (13 studies) through 'Sustainability' (Figure 5). A further 68 articles, which are not shown in Figure 5, were published in other journals. Focusing on the publication locations of the first authors, half of all publications originate from Europe (50\%), followed by Asia (26\%) and North America (17\%; Figure 6). 


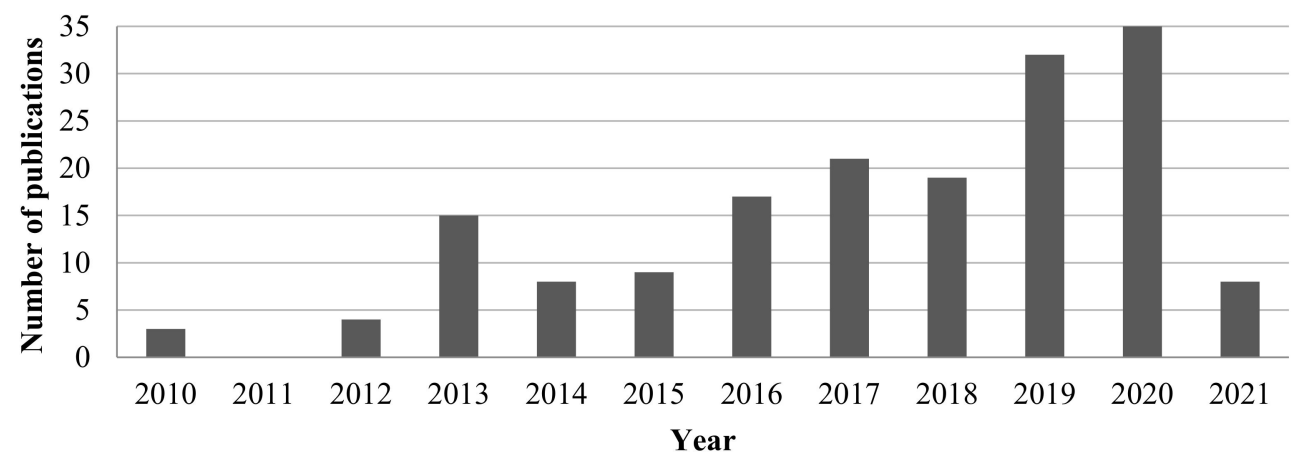

Figure 4. LCSA Publications from January 2010-February 2021.

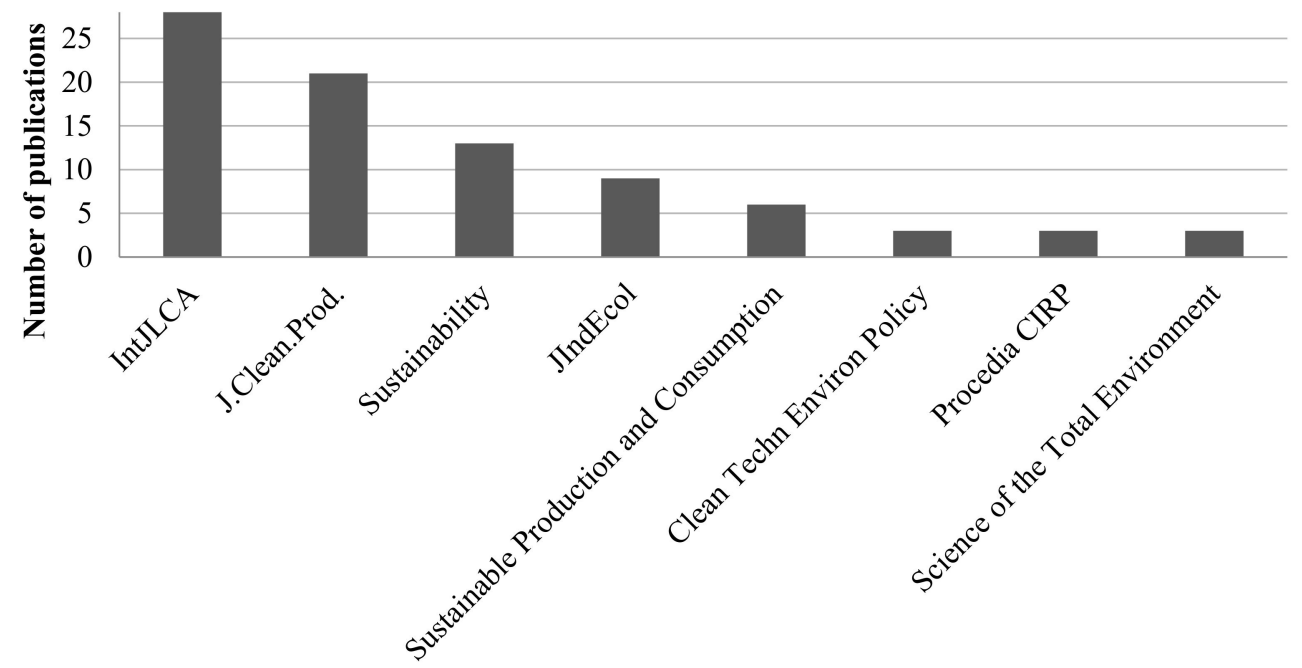

Figure 5. Journals used for publication.

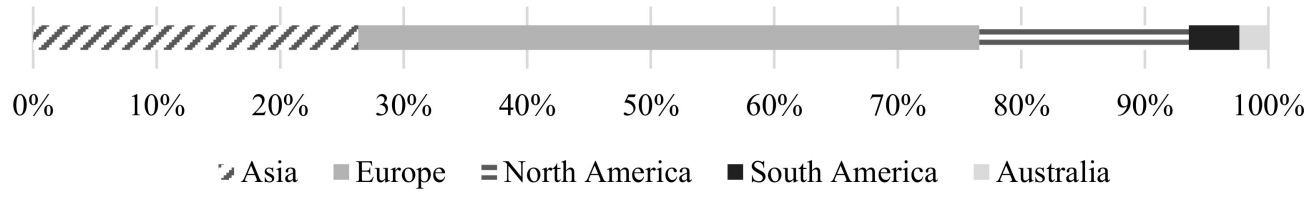

Figure 6. Working-Location of first authors.

Considering the LCSA publications classified as relevant for the construction sector, it was evident that almost one-third (29\%) of the 42 studies were published in the past year (2020; Figure 7). Also, for the field of LCSA studies with a focus on the construction sector, the journals 'IntJLCA' and 'J.Clean.Prod.' published the highest numbers of articles. The journal 'Sustainability' had no publications in the construction field (Figure 8). A further 26 publications appeared in individual journals or as book chapters. With regard to the first authors and their place of work, a difference became visible compared to the general statistics of the 171 publications. Europe, Asia and North America were more balanced (compared to the total of 171 publications) as publication locations, with Europe having published 38\% (16 studies) of the publications in the past ten years, North America 31\% and Asia 29\% (Figure 9).

It became obvious that no publications on the LCSA, in general and explicitly in the construction sector, had been made by African authors to date. Also obvious was the low number of publications from South America. These continents mainly face little industrial and economic activity, leading to low incomes and lower living standards for the general population. As a result, the field of construction in developing countries has made largely no progress in the last decade. There have not been many significant new works or 
knowledge breakthroughs [76], which might explain the lack of studies on sustainability in general and the LCSA in particular.

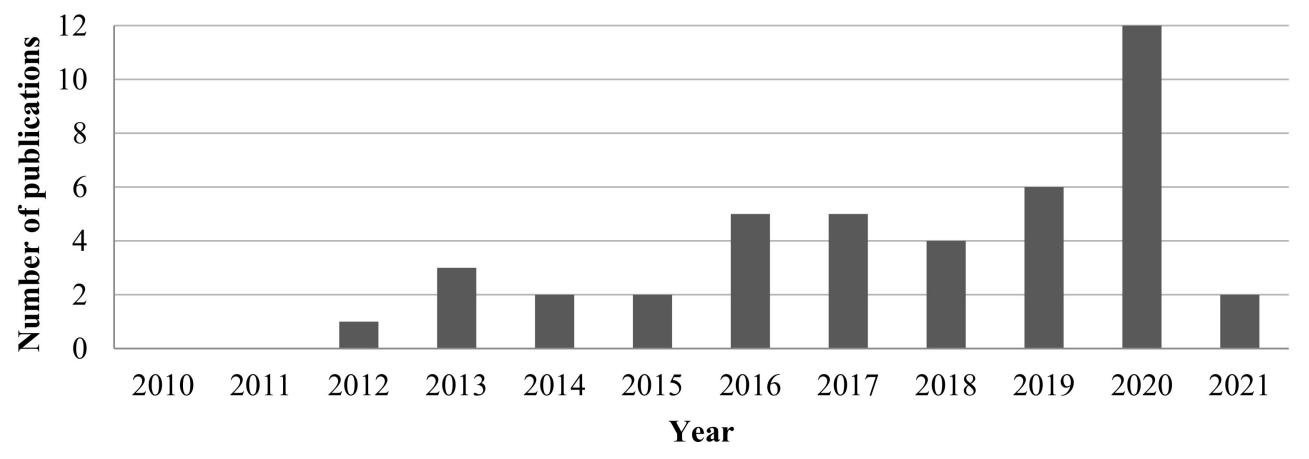

Figure 7. Construction-related LCSA publications from January 2010-February 2021.

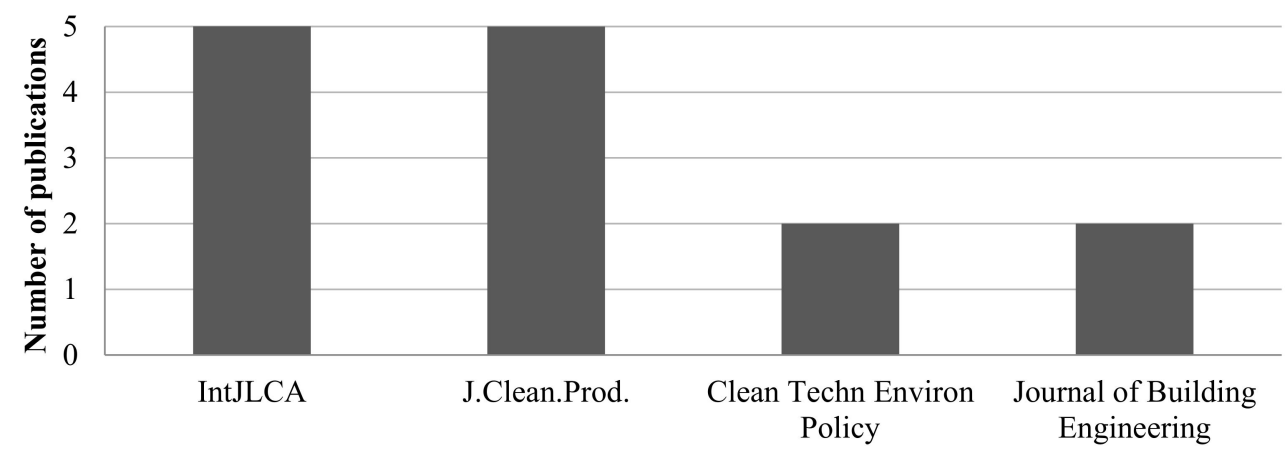

Figure 8. Construction-related journals used for publication.

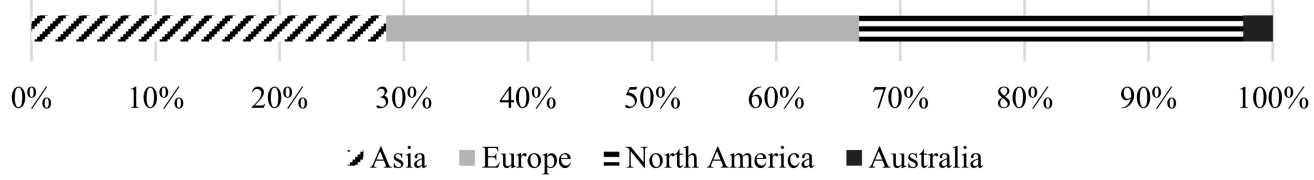

Figure 9. Working location of first author with a focus on construction sector.

In the following, the 42 LCSA construction sector studies were analyzed in detail. These could be split, as indicated, into reviews (14 studies), case studies (27) and one additional publication, which corresponds to a journal pre-face [77] (Figure 10). The 27 case studies and reported data were worked through in detail (methodological screening), resulting in a data matrix. Although all 27 studies included the term LCSA in their title, abstract, key words, introduction and conclusion, not all three pillars were assessed in the methodology and presented in results (Figure 11).

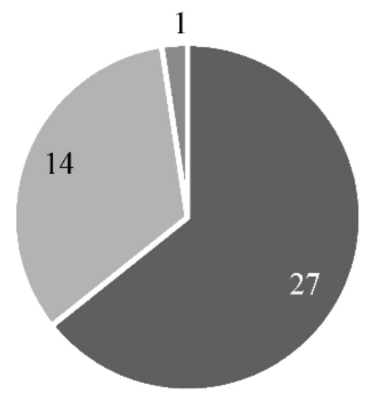

- Case Study " Review " Other

Figure 10. Article organization. 


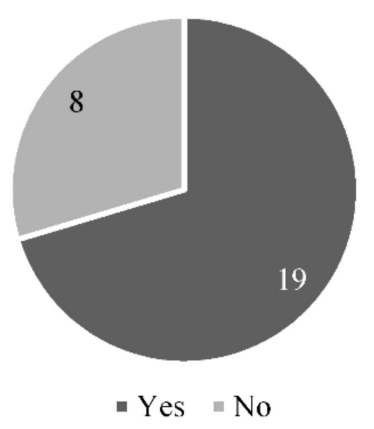

Figure 11. Assessing all three pillars.

Eight studies that mentioned all three pillars individually or the LCSA but did not assess them, considered:

- the relevance of the three pillars, without assessing them [78],

- the LCA only $[79,80]$,

- the LCA and LCC only, with the S-LCA not assessed [81-83],

- the LCA only combined with a socio-economic analysis $[84,85]$,

- the other three pillars, which were named as life-cycle cost assessment (LCCA), lifecycle structural performance assessment (LCSPA), and life-cycle environmental impact assessment (LCEIA) [79], and

- the detailed step-by-step description of how the LCSA could be implemented in practice, without undertaking a LCSA case study [86].

Out of the remaining 19 studies, three studies need to be named in detail, as they did not conduct a LCSA case study but conducted one Life Cycle Inventory (LCI) for all three pillars [87]; another study implemented a hypothetical case study but did not give a final result value [88] and the third study focused on the calculation of a developed sustainability index with indicators in the three dimensions [89].

\subsection{Case Studies (Steps 3 and 4)}

Thus, 19 different case studies were examined in detail (Table 1). The studies included windows, walls, buildings, resisting frames, dust control methods, cement, ceramic, dwelling, fly ash concrete and asphalt pavements (Table 1).

\subsubsection{Framework}

With regard to the FU, it became evident that the biggest challenge concerning its application was in the S-LCA, whereas for the LCA and LCC, the defined FU was not applied consistently [90-92]. Of the 19 studies, 18 showed defined system boundaries for the LCSA and 7 out of 19 studies performed a cradle-to-grave assessment. Six studies performed a cradle-to-use assessment (Figure 12). It is important to note that not all studies used these exact wordings for system boundaries, but instead named individual process steps, such as for example: raw material extraction to use, or raw material extraction, manufacturing, construction and operational phases [88,92-94], which makes them inconsistent with ISO 14040 (2006), the main international framework. For reasons of comparison, we recoded the individually named process steps to well-known system boundary definitions, following ISO 14040 (2006; Figure 12).

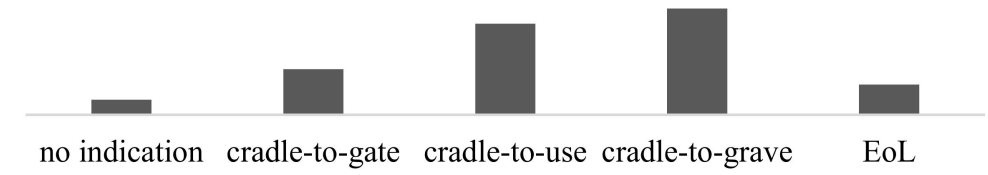

Figure 12. System boundaries used. 
Especially for the LCA, the following information were given: 12 case studies provided details of the software solution they used to conduct the assessments. Of the studies, $83 \%$ used SimaPro and $8 \%$ each used Athena LCI or GaBi (Figure 13). Furthermore, 12 out of the 19 case studies named databases: Ecoinvent was used in $42 \%$ of the studies, followed by the combination of Malaysia Life Cycle Inventory Database (MYLCID) and Ecoinvent (Figure 14). In 13 studies, the methodology applied was indicated: ReCiPe accounted for the largest share with $54 \%$ of use, followed by TRACI 2.0, IMPACT 2002 and Ecoindicator 99 (Figure 15). In this analysis, it was noticeable that relevant statements on implementation were missing; on average, only $66 \%$ of the studies specified their approach and the tools used. In addition, it became clear that the software solution $\mathrm{GaBi}$, which is frequently used in other studies and CML 2002, was hardly noticed or used [22,95,96].

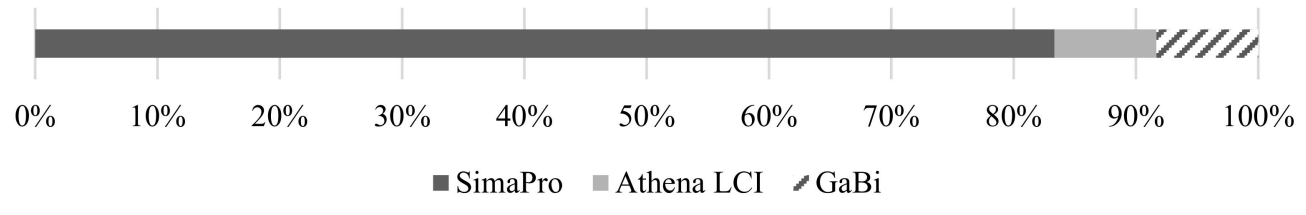

Figure 13. Software used.

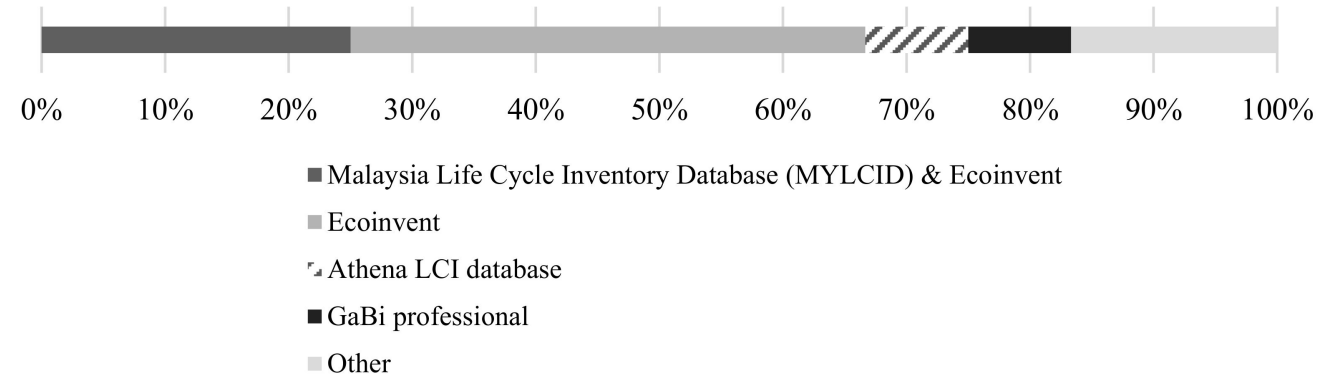

Figure 14. Databases used.

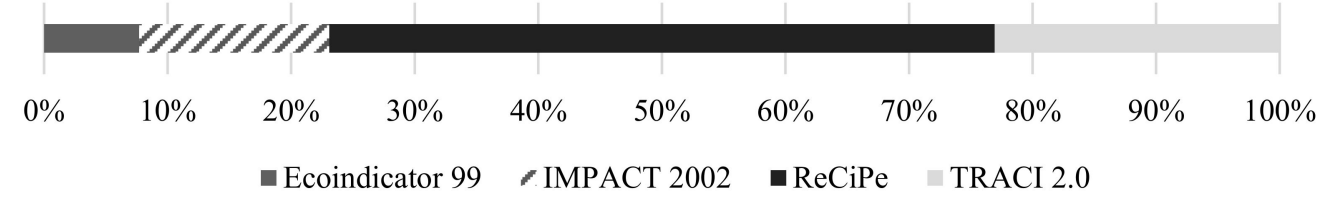

Figure 15. LCIA methodology used.

In 12 out of 19 case studies, the Life Cycle Inventory is based on fully or partly primary data. If only partly primary data is used, that is due to the fact that S-LCA data were collected via questionnaires but LCA data were mainly considered from the literature and databases (see e.g., $[5,79,80]$ ). For the S-LCA, the Social HotSpot database was used once [85], while PSILCA [97] as a social database was not mentioned. No specific databases were named for the LCC (Table 1). 
Table 1. Case studies analyzed.

\begin{tabular}{|c|c|c|c|c|c|c|c|c|c|c|c|c|c|c|c|c|c|c|c|}
\hline & & & & & & & & & & LCA & & & LCC & & S-LCA & & & & \\
\hline \# & Year & Content & Product & $\mathrm{FU}$ & $\begin{array}{l}\text { For All } \\
\text { Pillars }\end{array}$ & $\begin{array}{l}\text { Sys. } \\
\text { Bound. }\end{array}$ & $\begin{array}{c}\text { Primary } \\
\text { Data }\end{array}$ & Software & Database & Methodology & $\begin{array}{c}\text { \# of } \\
\text { Midpoint } \\
\text { Indica- } \\
\text { tors } \\
1\end{array}$ & $\begin{array}{l}\text { \# of } \\
\text { Endpoint } \\
\text { Indica- } \\
\text { tors } \\
2\end{array}$ & $\begin{array}{c}\text { \# of LCC } \\
\text { Indica- } \\
\text { tors } \\
3\end{array}$ & $\begin{array}{c}\text { Social } \\
\text { Aspects } \\
\text { Assessed }\end{array}$ & $\begin{array}{l}\text { Following } \\
\text { S-LCA } \\
\text { Guide- } \\
\text { lines } \\
4\end{array}$ & SHDB & Visualization & Weighting & $\begin{array}{l}\text { Weighting } \\
\text { Method }\end{array}$ \\
\hline 3 & 2020 & $\begin{array}{l}\text { sustainability } \\
\text { performance of } \\
\text { different concrete } \\
\text { and stone walls }\end{array}$ & $\begin{array}{l}\text { retaining } \\
\text { walls }\end{array}$ & $\begin{array}{l}\text { linear } \\
\text { meter of } \\
\text { wall for } \\
6 \mathrm{~m} \text { height }\end{array}$ & & $\begin{array}{l}\text { cradle-to- } \\
\text { grave }\end{array}$ & n.a. & SimaPro & $\begin{array}{l}\text { MYLCID } \\
\text { \& } \\
\text { Ecoinvent }\end{array}$ & ReCiPe & 2 & & 1 & $x$ & $x$ & no & & $\begin{array}{l}\text { 1) S-LCA } \\
\text { survey: } \\
\text { stakeholder } \\
\text { relevance; } 2) \\
\text { costs (33\%), } \\
\text { GWP }(24 \%), \text {, } \\
\text { OP (22\%), } \\
\text { social } \\
\text { aspects } \\
(20 \%)\end{array}$ & $\begin{array}{l}\text { MCDA: } \\
\text { AHP }\end{array}$ \\
\hline 5 & 2016 & $\begin{array}{l}\text { LCSA of building } \\
\text { constructions }\end{array}$ & $\begin{array}{c}\text { public } \\
\text { residen- } \\
\text { tial } \\
\text { building }\end{array}$ & & & $\begin{array}{l}\text { cradle-to- } \\
\text { use }\end{array}$ & yes & SimaPro & & ReCiPe & 17 & 3 & 1 & $x$ & & $\begin{array}{l}\text { no (but } \\
\text { SHDB } \\
\text { named) }\end{array}$ & & & \\
\hline 6 & 2016 & $\begin{array}{c}\text { hypothetical } \\
\text { analysis of } \\
\text { four-story } \\
\text { three-bay RC } \\
\text { moment resisting } \\
\text { frame }\end{array}$ & $\begin{array}{l}\text { resisting } \\
\text { frame }\end{array}$ & & & $\begin{array}{l}\text { cradle-to- } \\
\text { grave }\end{array}$ & $\begin{array}{l}\text { no (only } \\
\text { databases) }\end{array}$ & & Ecoinvent & & & & & & & no & & $\begin{array}{l}\text { to convert } \\
\text { individual } \\
\text { impact } \\
\text { categories to } \\
\text { one environ- } \\
\text { mental } \\
\text { performance } \\
\text { score } \\
\end{array}$ & - \\
\hline 7 & 2014 & $\begin{array}{l}\text { analysis of } \\
\text { mid-rise } \\
\text { residential } \\
\text { buildings: } \\
\text { concrete vs. wood } \\
\text { frame }\end{array}$ & $\begin{array}{l}\text { mid-rise } \\
\text { residen- } \\
\text { tial } \\
\text { building }\end{array}$ & $\begin{array}{c}1 \mathrm{ft}^{2} \text { hori- } \\
\text { zontal } \\
\text { area }\end{array}$ & & $\begin{array}{l}\text { cradle-to- } \\
\text { grave }\end{array}$ & yes & $\begin{array}{c}\text { Athena } \\
\text { LCI }\end{array}$ & $\begin{array}{l}\text { Athena } \\
\text { LCI } \\
\text { database }\end{array}$ & & 8 & & 1 & $x$ & $x$ & no & & $\begin{array}{c}\text { equal } \\
\text { weights for } \\
3 \text { pillars; } \\
\text { inter-pillar } \\
\text { weighting }\end{array}$ & $\begin{array}{l}\text { MCDA: } \\
\text { AHP }\end{array}$ \\
\hline
\end{tabular}


Table 1. Cont.

\begin{tabular}{|c|c|c|c|c|c|c|c|c|c|c|c|c|c|c|c|c|c|c|}
\hline & & & & & & & & & & LCA & & & LCC & & S-LCA & & & \\
\hline \# & Year & Content & Product & $\mathrm{FU}$ & $\begin{array}{l}\text { For All } \\
\text { Pillars }\end{array}$ & $\begin{array}{l}\text { Sys. } \\
\text { Bound. }\end{array}$ & $\begin{array}{c}\text { Primary } \\
\text { Data }\end{array}$ & Software & Database & Methodology & $\begin{array}{l}\text { \# of } \\
\text { Midpoint } \\
\text { Indica- } \\
\text { tors } \\
1\end{array}$ & $\begin{array}{c}\text { \# of } \\
\text { Endpoint } \\
\text { Indica- } \\
\text { tors } \\
2\end{array}$ & $\begin{array}{c}\text { \# of LCC } \\
\text { Indica- } \\
\text { tors } \\
3\end{array}$ & $\begin{array}{c}\text { Social } \\
\text { Aspects } \\
\text { Assessed }\end{array}$ & $\begin{array}{l}\text { Following } \\
\text { S-LCA } \\
\text { Guide- } \\
\text { lines } \\
4\end{array}$ & SHDB & Visualization Weighting & $\begin{array}{l}\text { Weighting } \\
\text { Method }\end{array}$ \\
\hline 8 & 2017 & $\begin{array}{l}\text { calculation of a } \\
\text { developed } \\
\text { sustainability } \\
\text { index with } \\
\text { indicators in the } \\
\text { three dimensions }\end{array}$ & $\begin{array}{l}\text { modular } \\
\text { building }\end{array}$ & $\begin{array}{l}\text { one } \\
\text { modular } \\
\text { building }\end{array}$ & & & n.a. & & & & & & & & & no & & \\
\hline 9 & 2019 & $\begin{array}{l}\text { LCSA of three } \\
\text { student housing } \\
\text { buildings }\end{array}$ & $\begin{array}{c}\text { student } \\
\text { housing } \\
\text { buildings }\end{array}$ & building & & $\begin{array}{l}\text { cradle-to- } \\
\text { use }\end{array}$ & yes & & Ecoinvent & ReCiPe & 0 & 3 & 1 & $\mathrm{x}$ & & no & & \\
\hline 10 & 2014 & $\begin{array}{l}\text { TBL economic } \\
\text { input-output } \\
\text { based hybrid } \\
\text { LCA model for } \\
\text { assessing US } \\
\text { residential and } \\
\text { commercial } \\
\text { buildings } \\
\end{array}$ & $\begin{array}{l}\text { US resi- } \\
\text { dential } \\
\text { and com- } \\
\text { mercial } \\
\text { building }\end{array}$ & building & & $\begin{array}{l}\text { cradle-to- } \\
\text { grave }\end{array}$ & $\begin{array}{c}\text { yes } \\
\text { (public } \\
\text { sources) }\end{array}$ & & & & 3 & & 3 & $\mathrm{x}$ & $\mathrm{x}$ & no & yes & \\
\hline 11 & 2021 & $\begin{array}{l}\text { LCSA of dust } \\
\text { control methods }\end{array}$ & $\begin{array}{l}\text { air/dust } \\
\text { control }\end{array}$ & $\begin{array}{l}\text { treatment } \\
\text { of an area } \\
\text { of } 0.4 \text { ha }\end{array}$ & & $\begin{array}{l}\text { cradle-to- } \\
\text { use }\end{array}$ & yes & GaBi & $\begin{array}{l}\text { GaBi pro- } \\
\text { fessional }\end{array}$ & $\begin{array}{l}\text { TRACI } \\
2.0\end{array}$ & 10 & & 1 & $\mathrm{x}$ & $\mathrm{x}$ & no & & \\
\hline 12 & 2019 & $\begin{array}{l}\text { LCSA of low } \\
\text { carbon cement in } \\
\text { Cuba }\end{array}$ & cement & $\begin{array}{l}1 \mathrm{t} \text { of } \\
\text { cement }\end{array}$ & & $\begin{array}{l}\text { cradle-to- } \\
\text { gate }\end{array}$ & partly & SimaPro & & ReCiPe & 11 & 3 & 1 & $\mathrm{x}$ & & no & yes & \\
\hline 14 & 2019 & $\begin{array}{l}\text { LCSA of the } \\
\text { Italian ceramic } \\
\text { sector }\end{array}$ & $\begin{array}{l}\text { ceramic } \\
\text { (wall tiles, } \\
\text { porcelain } \\
\text { stoneware) }\end{array}$ & $\begin{array}{l}1 \mathrm{~m}^{2} \text { of } \\
\text { ceramic }\end{array}$ & & $\begin{array}{l}\text { cradle-to- } \\
\text { grave }\end{array}$ & yes & SimaPro & Ecoinvent & $\begin{array}{l}\text { IMPACT } \\
2002\end{array}$ & 10 & 3 & 3 & $x$ & & no & yes & \\
\hline 15 & 2016 & $\begin{array}{l}\text { bottom ash } \\
\text { management, } \\
\text { waste } \\
\text { management in } \\
\text { Macao }\end{array}$ & $\begin{array}{l}\text { incinerator } \\
\text { bottom } \\
\text { ash }\end{array}$ & $\begin{array}{l}\text { treatment } \\
\text { of } 1 \mathrm{t} \text { ash }\end{array}$ & & EoL & partly & SimaPro & Ecoinvent & $\begin{array}{l}\text { IMPACT } \\
2002\end{array}$ & 15 & & 1 & $\mathrm{x}$ & & no & $\begin{array}{c}\text { env. } \\
\text { emissions } \\
\text { (39\%), } \\
\text { costs } \\
(35.2 \%), \\
\text { social } \\
\text { aspects } \\
(14.4 \%), \\
\text { legal, } \\
\text { aspects } \\
(11.4 \%)\end{array}$ & $\begin{array}{l}\text { MCDA: } \\
\text { AHP }\end{array}$ \\
\hline 16 & 2018 & $\begin{array}{c}\text { LCSA of } \\
\text { retrofitting a } \\
\text { private dwelling }\end{array}$ & dwelling & building & & $\begin{array}{l}\text { cradle-to- } \\
\text { use }\end{array}$ & n.a. & SimaPro & Ecoinvent & ReCiPe & 0 & 3 & 1 & $\mathrm{x}$ & $x$ & yes & & \\
\hline 17 & 2017 & $\begin{array}{l}\text { LCSA of fly ash in } \\
\text { concrete }\end{array}$ & $\begin{array}{l}\text { fly ash } \\
\text { concrete }\end{array}$ & $\begin{array}{l}1 \mathrm{~m}^{3} \text { fly } \\
\text { ash } \\
\text { concrete }\end{array}$ & & $\begin{array}{l}\text { cradle-to- } \\
\text { gate }\end{array}$ & $\begin{array}{l}\text { no (only } \\
\text { databases) }\end{array}$ & SimaPro & $\begin{array}{l}\text { European } \\
\text { Life Cycle } \\
\text { Database }\end{array}$ & $\begin{array}{l}\text { Ecoindicator } \\
99\end{array}$ & 4 & 3 & 3 & $\mathrm{x}$ & $x$ & no & $\begin{array}{l}\text { inter- } \\
\text { pillar } \\
\text { weight- } \\
\text { ing }\end{array}$ & $\begin{array}{l}\text { MCDA: } \\
\text { AHP }\end{array}$ \\
\hline
\end{tabular}


Table 1. Cont.

\begin{tabular}{|c|c|c|c|c|c|c|c|c|c|c|c|c|c|c|c|c|c|c|}
\hline & & & & & & & & & & LCA & & & LCC & & S-LCA & & & \\
\hline \# & Year & Content & Product & $\mathrm{Fu}$ & $\begin{array}{l}\text { For All } \\
\text { Pillars }\end{array}$ & $\begin{array}{c}\text { Sys. } \\
\text { Bound. }\end{array}$ & $\begin{array}{c}\text { Primary } \\
\text { Data }\end{array}$ & Software & Database & Methodology & $\begin{array}{c}\text { \# of } \\
\text { Midpoint } \\
\text { Indica- } \\
\text { tors } \\
1\end{array}$ & $\begin{array}{l}\text { \# of } \\
\text { Endpoint } \\
\text { Indica- } \\
\text { tors } \\
2\end{array}$ & $\begin{array}{l}\text { \# of LCC } \\
\text { Indica- } \\
\text { tors } \\
3\end{array}$ & $\begin{array}{c}\text { Social } \\
\text { Aspects } \\
\text { Assessed }\end{array}$ & $\begin{array}{l}\text { Following } \\
\text { S-LCA } \\
\text { Guide- } \\
\text { lines } \\
4\end{array}$ & SHDB & Visualization Weighting & $\begin{array}{l}\text { Weighting } \\
\text { Method }\end{array}$ \\
\hline 18 & 2020 & $\begin{array}{c}\text { LCSA of } \\
\text { pavement } \\
\text { alternatives }\end{array}$ & $\begin{array}{l}\text { highway } \\
\text { pavement }\end{array}$ & $\begin{array}{c}1 \mathrm{~km} \\
\text { pavement } \\
(3.5 \mathrm{~m} \\
\text { width) } \\
\end{array}$ & S-LC: & $\begin{array}{l}\text { cradle-to- } \\
\text { gate }\end{array}$ & partly & & & $\begin{array}{l}\text { TRACI } \\
2.0\end{array}$ & 5 & & 1 & $\mathrm{x}$ & & no & $\begin{array}{l}\text { intra- } \\
\text { pillar } \\
\text { weight- } \\
\text { ing }\end{array}$ & $\begin{array}{l}\text { MCDA: } \\
\text { AHP }\end{array}$ \\
\hline 19 & 2019 & $\begin{array}{c}\text { LCSA of } \\
\text { pavement } \\
\text { alternatives }\end{array}$ & $\begin{array}{l}\text { asphalt } \\
\text { concrete } \\
\text { layer }\end{array}$ & $\begin{array}{c}1 \mathrm{~km} \\
\text { pavement } \\
(3.5 \mathrm{~m} \\
\text { width })\end{array}$ & $\begin{array}{l}\text { no: } \\
\text { S-LCA }\end{array}$ & $\begin{array}{l}\text { cradle-to- } \\
\text { use }\end{array}$ & partly & & GREET & $\begin{array}{c}\text { TRACI } \\
2.0\end{array}$ & 5 & & 1 & $\mathrm{x}$ & & no & $\begin{array}{l}\text { intra- } \\
\text { pillar } \\
\text { weight- } \\
\text { ing }\end{array}$ & $\begin{array}{l}\text { MCDA: } \\
\text { AHP }\end{array}$ \\
\hline
\end{tabular}

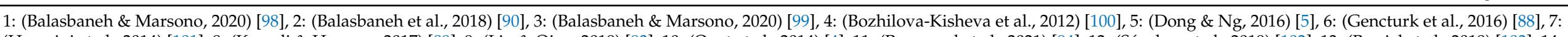

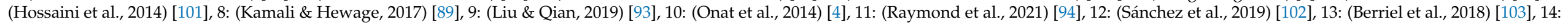
(Settembre Blundo et al., 2019) [104], 15: (Sou et al., 2016) [105], 16: (Touceda et al., 2018) [85], 17: (Wang et al., 2017) [106], 18: (Zheng et al., 2020) [91], 19: (Zheng et al., 2019) [92] 


\subsubsection{Assessment \\ LCA}

The examination of the individual assessments showed differences in the standardized LCA $[23,107]$ : Seven out of 19 case studies considered three endpoint indicators: human health, ecosystem and resources (Table $1^{1,2}$ (\# of midpoint and endpoint indicators)). Five of these seven studies considered midpoint and endpoint indicators, while two others referred only to the endpoints. The number of reported midpoint indicators ranged from one to 17 (Table $\left.1^{1,2}\right)$. Assessing midpoint indicators, GWP $\left(\mathrm{kg} \mathrm{CO}_{2 \mathrm{e}}\right)$ was assessed and mentioned in every study $(100 \%)$. Partly named were Acidification Potential (AP; kg $\mathrm{SO}_{2 \mathrm{e}}$ ), Eutrophication Potential (EP; $\mathrm{kg} \mathrm{N} \mathrm{N}_{\mathrm{e}}$ ), Ozone Depletion Potential (ODP; $\mathrm{kg} \mathrm{CFC}-11_{\mathrm{e}}$ ), Primary Energy (CED; GJ) and Freshwater Ecotoxicity (FE; kg 1.4-DBe; Figure 16). A further 21 midpoint indicators were analyzed (named and assessed $\leq 4$ times). Fifty percent of the studies presented absolute values for the midpoint indicators. The remaining presented percentages or graphics.

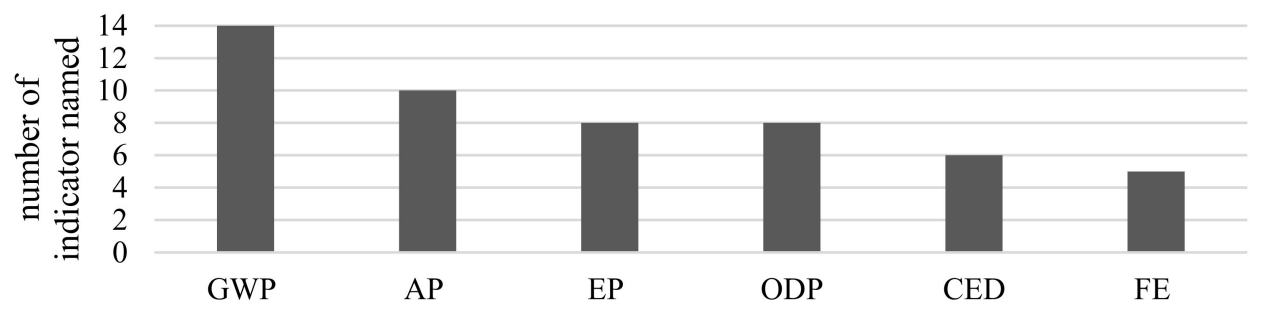

Figure 16. LCA: midpoint indicators assessed and named.

LCC

Eight studies mentioned the Net Present Value (NPV) as key indicator. Two studies explicitly mentioned project costs as indicator. The remaining studies mentioned other indicators (Figure 17, Table $1^{3}$ ) that were used for Life Cycle Cost analysis in the LCSA: foreign purchasing (imports), business profit and gross domestic product (GDP) [4]; purchase costs associated with materials and fuel use and vehicle/equipment rental over the life cycle [94]; production costs, utilization costs and externalities [104]; total discounted cost of constructing, operating and maintaining the equipment and the total discounted benefit of selling recycled products [105]; the costs of energy consumed in concrete preparation, fuel consumed in transportation and raw material costs [106] and a combined approach with the social dimension [85].

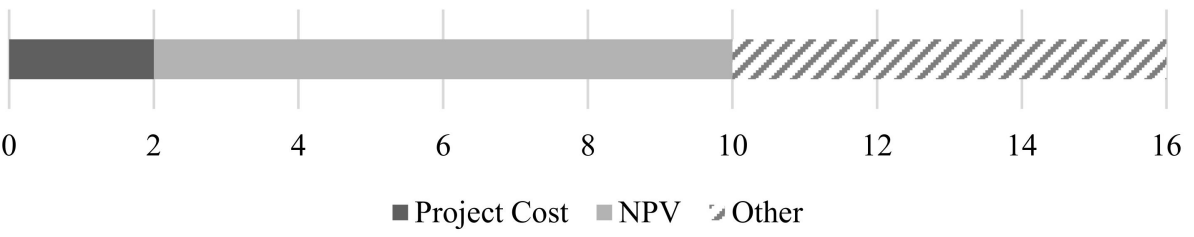

Figure 17. LCC: indicators assessed.

S-LCA

Thirty-eight percent of the studies followed the S-LCA guidelines [20,25] (Table $1^{4}$ (Following S-LCA guidelines)). Alternative social indicators or stakeholder groups were named as: capacity for job creation, salary status, aesthetics, suitability of location, health and safety and local supply [90]; stakeholders considered were workers, the local community and society [99]. The main 'subcategories' considered were occupant comfort, safety, fire resistance and affordability (Hossaini et al., 2014); income, government tax and injury [4]; social costs of carbon, methane and nitrous oxide. These were computed and summed [94] and a combined approach with the economic dimension (named as socioeconomic approach by Touceda et al. (2018) [85]. As can observed, the subcategories 
considered were not consistent with the S-LCA guidelines. Indeed, the affordability and social costs of emissions were not consistent with the UNEP 2020 guidelines and the main S-LCA references. In addition to the large number of subcategories and related indicators, often the methodology used or applied was inadequately described or not described at all (missing information about assumptions, decisions made, data and stakeholder, subcategories, etc., chosen and used). The studies that explicitly mentioned and followed the guidelines made full use of the impact and subcategory called Health and Safety (Figure 18).

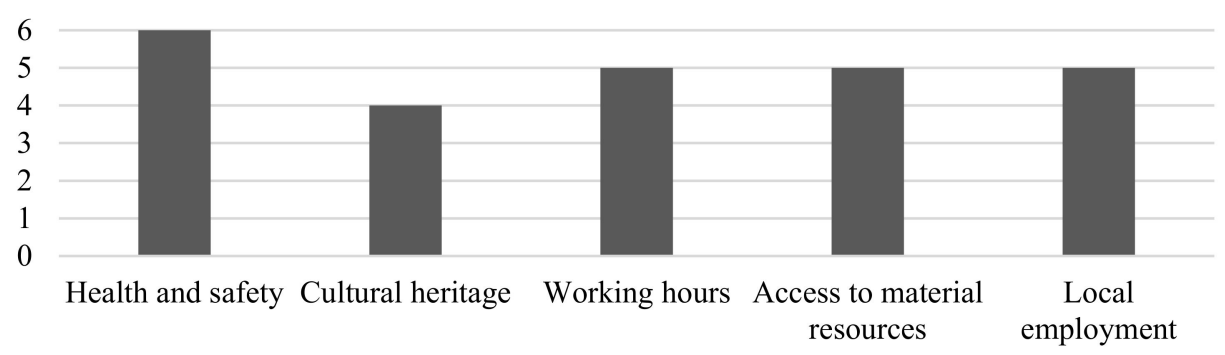

Figure 18. The S-LCA concerning S-LCA guidelines: Indicators assessed.

Interpretation, Visualization and Weighting

Despite the mentioned relevance of LCSA result visualization [30,108], only $21 \%$ (four studies) of the analyzed case studies made use of visualization (Table 1). Two out of four studies applied the sustainable triangle [13] in an extended form. Another two studies presented individual graphs, which were not based on a known visualization option for the LCSA $[13,29,30]$. Eight out of 19 studies applied selective weighting (Table 1), fully using the Analytical Hierarchy Process (AHP). Weighting was applied to the pillars (LCA vs. LCC vs. S-LCA) $[91,92,98,99,105]$, which contradicts the approach of Kloepffer and Finkbeiner [13,14]. Impact categories were combined into one indicator through further weighting [88], and weights were applied to indicators within a pillar [101,106]. To return to the beginning of the article and the rating systems or schemes used (LEED; BREEAM or in Germany DGNB), only four (21\%) of the 19 case studies mentioned rating schemes or made a reference to them. No further details were mentioned; they (4x LEED, 1x BREEAM) served as an introduction or future outlook topic only $[85,89,93,94]$.

\section{Discussion (Step 4)}

The aim of the actual structured literature review was to define whether and how the LCSA is applied and interpreted in the construction sector today, defined by the initial research question: Does the LCSA find applications in the construction sector, and if so, how and to what extent?

The LCSA is being applied in the construction sector, although to date only a small number of studies have considered all three pillars: $25 \%$ of all 171 studies focused on the construction sector and only $11 \%$ of all studies were conducted on the LCSA in the construction sector. These results mirror the statements of other studies [58-60,68,77,109]. It became evident that both non-construction-specific LCSAs and those related to the construction sector, in 2020, reached the highest publication numbers to date. Interestingly, the rising number of LCSA studies in the construction sector is accompanied by a rising numbers of challenges, which are named in detail in Section 6.1.

1. Do LCSA studies follow the initial approach of Finkbeiner et al. (2010) and Kloepffer (2008)?

In three of 19 case studies, the FU could not be applied to all three assessments; the S-LCA was the main pillar not being implemented with the defined FU [90-92]. Further, differently defined lifespans of the buildings among the different studies make a comparison of the studies and their results complex $[58,68,110]$. Table 1 shows that five out of eight studies applied weights to the individual pillars, which did not meet the requirements of equal assessments [13,14]; even the problem of personal bias of the authors was mentioned 
concerning weighting [81]. Other studies did not follow the LCSA approach by, e.g., evaluating economic, environmental and social impacts and weighting them to a final new value [88]. The remaining considered the approach, although it had become apparent that interpretation and combination of the three pillars faced difficulties (see, e.g., $[5,74,90])$.

Often, the focus of the studies was set to be on environmental issues (see, e.g., 46,53,54]) rather than an approach to emission reduction and resource optimization. Solution approaches or optimization proposals explicitly on material, production steps or recycling strategies were not given. All three pillars were presented individually and the results between scenarios were reconciled, but no link between the three pillars was created. The decision maker gets three individual results and still does not know how to continue further [94].

The following research questions were posed:

2. How many and which indicators are applied and reported per pillar (LCA, S-LCA, LCC)?

3. Which results are depicted and how are they interpreted?

\section{LCA}

The number and selection of indicators per individual assessment varied widely: with one to 17 midpoint indicators, all studies that considered the midpoint indicators mentioned and assessed GWP. In four cases, only GWP was considered, which represents a $\mathrm{CO}_{2}$ footprint. Less than half of the studies (31\%) reported more than five impact indicators. This indicates a lack of completeness of LCAs in the construction sector. The FU was not clearly defined in every paper, which leads the reader or decision maker to further uncertain assumptions (see, e.g., [5]). Life cycle stages were not necessarily named or defined according to the ISO norms, but represented processes that could be subjectively ordered into the normed system boundaries. Due to this, a comparison of studies and results becomes even more difficult. Clear replicability is not guaranteed. The inventories were insufficiently described, the exact data basis remained unclear (partly primary data, partly secondary data, partly no information at all (Table 1)) and the process of selection for software solutions and databases was not transparent. Due to the high emissions and resource consumption of the construction sector, one might expect that optimization approaches regarding production and material composition would be targeted. These optimization and reduction ideas were not given in the studies, especially in the LCA part, and due to the non-transparent inventory, it is not feasible for the reader and, e.g., environmental engineers to understand the values and possibly work on optimization approaches. The results themselves were reported as absolute numbers, percentages or graphs. Relevant and in need of improvement are the details and information on FU, databases, exact procedures, justified indicator selection, etc., which were partly missing $[4,5,91-93,98,101-103]$. In particular, a very deliberate and well-founded selection of the functional unit is relevant in the construction sector. If, for example, two products are compared in the FU of $1 \mathrm{~kg}$ (e.g., carbon fiber vs. steel) and then again in the actual function of a reinforcement (e.g., fiber vs. steel reinforced concrete), for example, this results in two completely different statements. One evaluation would prefer steel, the other fibers, as both show significantly less emissions than the other.

\section{LCC}

In analyzing the economic and social pillars, the environmental focus remained paramount. None of the studies analyzed placed more 'weight' on economic or even social aspects than on the environmental aspect, even if the challenges mentioned record incomplete LCAs ( $<5$ impact indicator; GWP single indicator). A closer look revealed that hardly any study named and justified the explicitly applied LCC method. Furthermore, the costs named and considered as relevant varied in the studies; for example, on the one hand, capital, labor, energy, waste, other costs and paybacks were named; on the other hand, only project costs were named, missing an explanation of what was included in the project costs. One study [102] focused additionally on depreciation but named the relevant costs 
differently than other studies with salary, consumption, energy and transport costs. The economic approach seems to be more tangible for authors and readers as it is expressed in a globally known and used quantity: a monetary value. Nevertheless, it is clear that a consistent approach is lacking. Replicability is not given, which seems understandable in part since primary financial data cannot be published for reasons of secrecy; yet, it remained unclear which costs were explicitly considered and added up and whether and how the lifetime of the building or the material were significant in terms of the costs (depreciation). The numbers of indicators evaluated and reported ranged from one to three (Table 1), with $42 \%$ of studies using the Net Present Value (NPV) as an indicator, $10 \%$ reporting project costs as an indicator and the remainder used other definitions. For example, purchase costs associated with materials and fuel use and vehicle/equipment rental over the life cycle [94], energy consumed in concrete preparation, fuel consumed in transportation, or raw material [106] were reported. Further levels of detail were missing and, in these cases, no explicit social costs are reported (such as, e.g., wages). In conclusion, no reference was made to the other two pillars and a holistic statement or even optimization was not named. A more unified approach, following existing guidelines, is essential if the building sector is to be supported in terms of a holistic approach and optimization.

\section{S-LCA}

From a construction-sector perspective, social sustainability means providing a healthy and safe environment for all stakeholders throughout the processes [111,112]. Construction materials and buildings represent complex assemblages of diverse raw materials. Social conditions are dynamic, so social data change more rapidly compared to environmental data [113]. The complex stakeholder situation in construction processes complicates the assessment of social sustainability, and relevant stakeholders are not all adequately covered in S-LCA studies $[93,114]$.

The main challenges identified were the selection and quantification of social criteria and indicators. There was no consensus on appropriate indicators, nor a standardized approach $[115,116]$, uniform, clear communication $[5,90]$ or a steady and actual implementation of S-LCA [81]. Although the S-LCA guidelines have been published for over 10 years and were revised again in 2020 [20,25], only $8 \%$ of studies referred to these guidelines (Table 1). All other studies used further and individual indicators as social cost of Greenhouse Gas (GHG) emissions, job creation, professional growth, contribution to growth, fair employment and the fuel poverty gap $(€)[4,83,85,87,90,94,101]$. Table 2 shows that the social focus of the construction sector was mainly on the worker, local community and society stakeholders. The most relevant subcategories were health and safety, working hours, access to material resources and local employment.

From the occupants' point of view, the use phase is relevant in the building sector, but only a few identified and named subcategories (Table 2, e.g., safe and healthy living conditions) refer to this part of life cycle. More subcategories refer to the production stages, which is not necessarily in line with Figure 12 (system boundaries), where more studies go beyond the production stage. In particular, with regard to the lifetime of buildings and building products, further subcategories such as public commitments to sustainability issues (e.g., with regard to recycling, circularity, renovation of old buildings, innovative building materials, etc.) and technology development (e.g., with regard to innovative building materials such as carbon concrete or new production methods such as 3D-printing) would be relevant for society and, for example, end-of-life (EoL) responsibility and also transparency (e.g., with regard to raw materials, production, dismantling, etc.) for consumers. Due to partly scarce raw materials, such as sand in concrete [117], the evaluation of supplier relationships would also be of greater interest for the construction sector (stakeholder categories: value chain actors). The aspects mentioned in LEED, BREEAM or DGNB, for example, increasingly refer to the user of the building (use phase) and consider social aspects such as comfort or health effects. The subcategories determined in the S-LCA have a different focus. Obviously, there is a missing link between rating 
systems and sustainability assessments. Scientific studies made little or no reference to these systems.

Table 2. Subcategories and stakeholders assessed and reported.

\begin{tabular}{ccc}
\hline Stakeholder Categories & Subcategories & Frequency \\
\hline Workers & Health and Safety & 6 \\
& Working hours & 5 \\
& Freedom of association and collective & 1 \\
bargaining & 1 \\
& Child labor & 1 \\
& Fair salary & 1 \\
Focal Community & Equal opportunities & 1 \\
& Access to material resources & 5 \\
& Local employment & 5 \\
& Cultural heritage & 4 \\
& Safe and healthy living conditions & 2 \\
Community engagement & 1 \\
& Safe and healthy living conditions & 1 \\
\hline Society & Technology development & 4 \\
& Contribution to economic development & 2 \\
& Public commitments to sustainability issues & 3 \\
\hline
\end{tabular}

\subsection{Main Challenges}

Even if the LCSA is expected to increase interest in the construction sector $[5,58,65,77]$, construction projects are constrained by high time pressure in the industry, resulting in a lower priority for sustainability. The research results suggest the following aspects as main challenges (4. Are any challenges evident in the studies, and what are they?) that can be optimized in future:

- A clear definition of LCSA, LCA, LCC and S-LCA exists through Hunkeler et al. (2008), ISO 14040 (2006), ISO 14044 (2018), UNEP $(2009,2011,2020)$ and Valdivia et al. (2013) $[20,21,23,25,44,107,118]$. Indicators are further given through these definitions. Nevertheless, studies were implemented and published that did not follow the definitions. Only $11 \%$ of the studies reviewed did a full LCSA. For the LCA, all studies made use of GWP as an indicator but only 30\% assessed and reported more than four further indicators (focusing more on the $\mathrm{CO}_{2}$ footprint than on a full LCA). For the LCC in the reviewed studies, there was no consensus that specified costs to focus on. Of the studies reviewed, $42 \%$ reported NPV as an indicator, while others made use of product costs or further individual indicators. For the S-LCA, the focus was on the production, which is contradictory to the defined system boundaries, further including the use phase and respective stakeholders.

- LCSA-based decision making in the construction sector is limited to research and rarely used or applied in practice $[109,119]$. The studies reviewed did not focus on material/product optimization or production improvements. The decision maker/reader at the end is left alone with the assessments and the interpretation.

- To date, the holistically named sustainability assessment often focuses more intensively on environmentally sustainable construction methods and materials to minimize environmental impacts [101]. In this review, economic and social aspects were neglected-shown by only $11 \%$ of the reviewed articles assessing all three pillars.

- There is a lack of cohesion between disciplines [60]. Harmonization of different tools and methods to a common system language/understanding is needed. Specifically, focusing on the thematic backgrounds of the authors, one finds mainly civil engineers. Environmental engineers or even social scientists or business economists were missing. This might explain the inconsistencies regarding service life integration, the cost consideration and stakeholder involvement in the use phase. 
- In the studies reviewed, the interpretation and processing of the results for nonexperts was not the focus. A harmonization of 'must-use' indicators and a visualization approach could make the results more understandable and harmonious, especially for non-experts. Further, this would ensure improved reproducibility and 'simplified' LCSA processing. Especially for the S-LCA, mainly the production phase has been considered so far, though the use phase and the service lifetime are of great importance in the building sector. A more intense focus might be of relevance for the building sector.

- In order to ensure comprehensibility and comparability, the precise definition and justification of selected FU, system boundaries and indicators is absolutely relevant. In the studies analyzed, remarkably little justification was given for assumptions and decisions. Often, a variety of materials and material compositions come together in the building sector. Also, innovation—such as, e.g., carbon concrete-in the building sector becomes important in view of the high emissions. These early and detailed assessments are especially important in order to work on optimization with regard to all three dimensions of sustainability in the design process. Clearly defined assumptions and decisions are of great importance for long-term, life cycle-accompanying and future EoL assessments.

\subsection{Study Limitation}

In order to meet the disordered, rising interest in the field of sustainable construction design with a clear framework, systematic studies were used since they provide an objective, modern overview by including strict inclusion and exclusion rules. The research results presented and the derived proposals for LCSA application in the construction sector are rooted in the analysis of the latest 171 English-language publications between 2010 and 2021. Journals in respective national languages (e.g., German, Italian, etc.) and from before 2010 were not included in the review. The general approach and understanding of the LCSA were broken down into 42 publications specifically belonging to the construction sector and the respective application of the LCA, S-LCA, LCC and LCSA concerning Finkbeiner et al. (2010) and Kloepffer $(2008)[13,14]$. Since this narrowing down was decided based on the empirical knowledge of the authors, other multidimensional assessment approaches to sustainability — such as material flow analysis-were excluded. Detailed searches were conducted of the two aforementioned databases; non-peer-reviewed conference publications were not examined. The results showed the respective author countries (Figures 6 and 9); however, the focus was only on the first author and did not consider the countries of activity of the other authors. Furthermore, it would have been interesting to know from which subject area the publications originated. The indicative results could not be compared or normalized because hardly two studies could really be compared due to different products and FUs (Table 1).

\section{The Way Forward (Step 4)}

The fifth and final research question posed was: What anchors the LCSA and the construction sector? How could implementation strategies further be improved?

To briefly answer this research question in advance: Yes, we need the LCSA in its actual form to support the construction sector. There is no need to innovate as the relevant tools exist and further approaches will only complicate the LCSA for decision makers in the construction sector. In order to address the defined challenges and to provide an idea of how a future approach could look, the following ideas are given:

1. As shown in Section 5.1, a large number of scientific publications can be found in which the LCSA term is not correctly used (in an extreme case, a 'simple' GWP assessment was framed as 'LCSA'). At this point, it should not be speculated about possible causes. The correct application of the LCSA implies it consists of all three assessments: environmental, economic and social aspects. 
2. It makes sense to fully utilize the current approaches instead of constantly including new indicators in the assessments. As presented in Section 2.1, the completeness of commonly accepted and standardized sustainability impact categories or subcategories-such as given by the S-LCA guidelines-is diluted throughout the green building rating systems such as, e.g., LEED, DGNB and BREEAM. Sustainability approaches should be linked more closely to rating systems and vice versa, as proposed by Level(s) [120] (see Table A1). That would serve to integrate sustainability assessments in certification or rating systems (whenever in the life cycle) and to connect the assessment with the rating system to increase awareness of the assessment and its requirements (e.g., especially for non-construction-experts).

3. In particular, for the scientific community, it should be mandatory to describe exactly how and why methodologies, system boundaries and FUs, indicators, etc., have been applied. No publication should be published with missing information on the named aspects; replicability should be ensured.

4. Similarly, the goal of science should be to view LCSA results as a solution and optimization effort, and not to leave them purely as absolute or percentage numerical values. This could narrow the gap between disciplines and encourage more practitioners to undertake sustainability assessments further linked with rating or certification schemes.

A unified LCSA approach, which, for example, includes a set of predefined indicators such as the Tiered Approach [28] or which follows the Level(s) approach [120] (see Tables A1 and A2), could provide a lower barrier to enter into the LCSA topic. It would help if it were further supported by a visualization tool such as the Sustainability Triangle [13]. Besides that, especially in the construction sector, it might be important to understand from practitioners what sustainability means and whether the LCSA and/or rating schemes are (not) being used in practice, to make purely scientific approaches more practicable.

\section{Conclusions}

By applying a systematic literature review, quantitative-qualitative content analysis methods were used to identify the application and challenges of the Life Cycle Sustainability Assessment in the resource- and energy-intensive construction industry. The Life Cycle Sustainability Assessment combines the three sustainability pillars-environmental, economic and social— to evaluate products and services over their life cycle. The aim of this strategic literature review was to answer the main research question: Does the LCSA find applications in the construction sector, and if so, how and to what extent? In this study, 171 studies were reviewed in detail, of which 42 were of relevance to the construction sector; all of the studies were published between 2010 and 2021 as peer-reviewed literature. Only $11 \%$ of studies reviewed did a full LCSA. Europe, North America and Asia were balanced publication continents and the number of publications peaked in 2020. Although clear definitions of the individual assessments are existing, studies were implemented and published that do not follow the definitions and methodologies. A large number of scientific publications could be found in which the LCSA term was not correctly used and economic and social aspects were neglected. The completeness of commonly accepted and standardized sustainability indicators was partly diluted throughout the use of further indicators and missing linkages to green building-rating systems. Results were presented in absolute, percentage and graphical ways, missing methodological explanations and optimization approaches. Furthermore, five research questions were answered, for the last of which a solution approach is presented: What anchors the LCSA and the construction sector? How could implementation strategies further be improved? There is no need to innovate: A unified LCSA approach that includes a set of predefined indicators further supported by a visualization tool could provide a lower entry barrier to anchor the LCSA in the building and construction sector. 
Author Contributions: Conceptualization, J.G.B.; methodology, J.G.B.; validation, J.G.B. and M.T.; formal analysis, J.G.B.; investigation, J.G.B.; resources, J.G.B.; data curation, J.G.B.; writing-original draft preparation, J.G.B.; writing-review and editing, J.G.B. and M.T.; visualization, J.G.B.; supervision, M.T.; project administration, J.G.B. and M.T.; funding acquisition, M.T. and J.G.B. All authors have read and agreed to the published version of the manuscript.

Funding: This research was funded by the German Research Foundation (DFG), as part of the Sonderforschungsbereich/Transregio 280 (SFB/TRR 280) 'Konstruktionsstrategien für materialminimierte Carbonbetonstrukturen' /'Design Strategies for Material-Minimized Carbon Reinforced Concrete Structures' (Subproject E01, project number 417002380). The financial support by the German Research Foundation (DFG) is gratefully acknowledged.

Institutional Review Board Statement: Not applicable.

Informed Consent Statement: Not applicable.

Data Availability Statement: Not applicable.

Conflicts of Interest: The authors declare no conflict of interest.

\section{Appendix A}

Appendix A.1. Level(s)

Level(s) is a common voluntary assessment and reporting framework launched in 2017 by the European Commission's Joint Research Centre that includes a set of indicators (16) and common metrics for assessing the sustainability of office and residential buildings along their life cycle. The target audience of Level(s) is professionals who play a role in the planning, design, financing and execution of building projects, such as design teams, architects, clients, owners and public policymakers. The goal of Level(s) is to provide a common language of sustainability. All stakeholders should be able to make a clear contribution to comprehensive environmental improvements at the European level [120]. Similar to the LCSA, Level(s) considers three thematic areas of sustainability: Resource use and environmental performance, Health and comfort, and Cost, value and risk. Six macro-objectives further subdivide these areas, and 16 indicators can be assigned to the individual macro-objectives. Level(s) makes partial use of the LCA and LCC but simplifies the complexity of the assessments with a significantly smaller number of indicators (see Table A1, Indicators).

Table A1. Level(s) matrix.

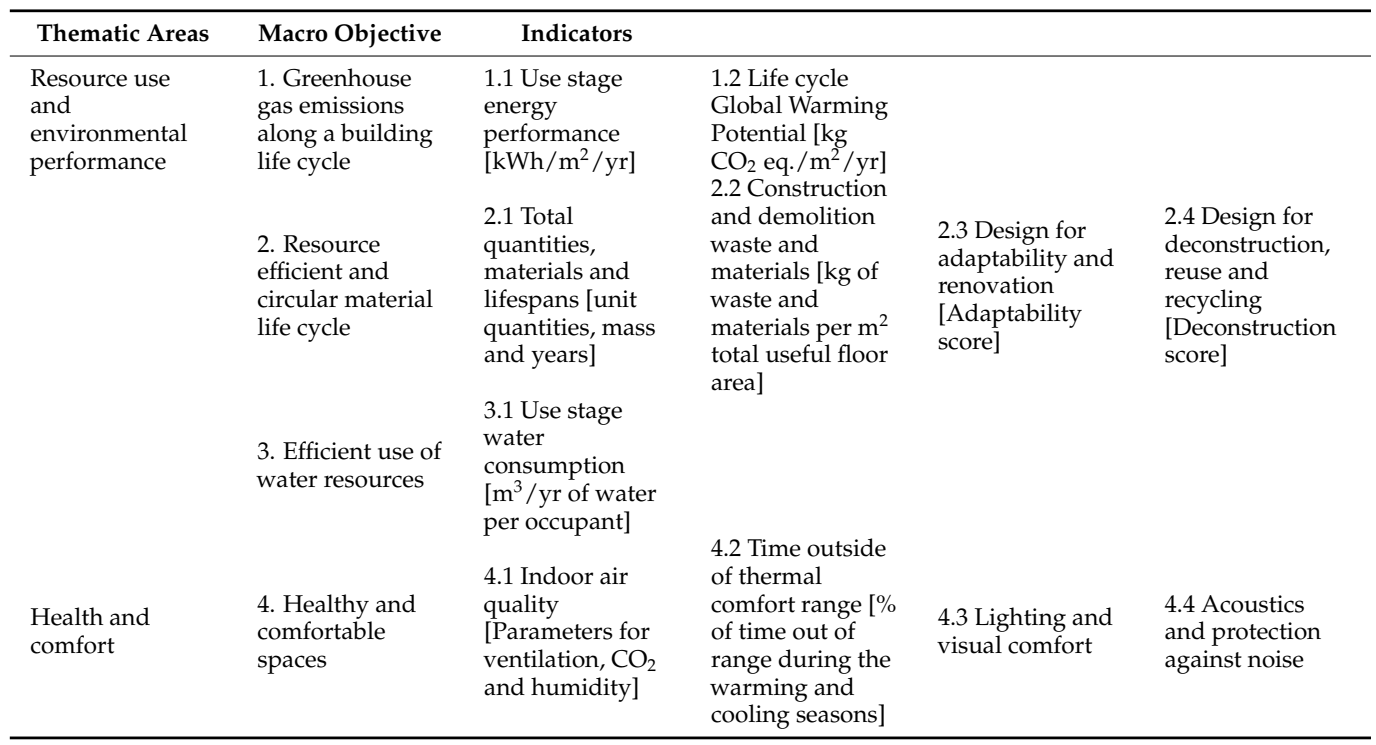


Table A1. Cont.

\begin{tabular}{|c|c|c|c|c|}
\hline Thematic Areas & Macro Objective & Indicators & & \\
\hline \multirow[t]{2}{*}{$\begin{array}{l}\text { Cost, value and } \\
\text { risk }\end{array}$} & $\begin{array}{l}\text { 5. Adaptation } \\
\text { and resilience to } \\
\text { climate change }\end{array}$ & $\begin{array}{l}5.1 \text { Protection of } \\
\text { occupier health } \\
\text { and thermal } \\
\text { comfort } \\
\text { [Projected \% } \\
\text { time out of range } \\
\text { in years } 2030 \text { and } \\
2050 \text { ] }\end{array}$ & $\begin{array}{l}5.2 \text { Increased risk } \\
\text { of extreme } \\
\text { weather events }\end{array}$ & $\begin{array}{l}5.3 \text { Increased risk } \\
\text { of flood events }\end{array}$ \\
\hline & $\begin{array}{l}\text { 6. Optimized life } \\
\text { cycle costs and } \\
\text { value }\end{array}$ & $\begin{array}{l}\text { 6.1 Life cycle } \\
\text { costs }\left[€ / \mathrm{m}^{2} / \mathrm{yr}\right]\end{array}$ & $\begin{array}{l}6.2 \text { Value } \\
\text { creation and risk } \\
\text { exposure }\end{array}$ & \\
\hline
\end{tabular}

\section{Appendix A.2. Tiered Approach}

The Tiered Approach is a stepwise approach for LCSA indicator implementation. Three tiers-named Tier 1 (Sustainability Footprint), Tier 2 (Best Practice) and Tier 3 (Comprehensive Approach)—have been defined, facilitating the LCSA practice. Based on three predefined key criteria (namely, relevance, robustness and practicability), applied to midpoint indicators of the LCA and S-LCA subcategories and two cost categories of LCC, the Tiered-Approach indicators were assigned to the respective tiers. For Tier 1, which is the most basic and lest complicated stage, indicators with high practicality and good data availability were chosen. Tier 2, going into more detail, included Tier 1 indicators and indicators according to suggestions from international institutions. The most detailed Tier 3 was meant to complement the indicator selection in Tiers 1 and 2 for all three dimensions [28] (see Table A2).

Table A2. Tiered approach.

\begin{tabular}{cccc}
\hline & & Indicators & \\
\hline Tier & LCA & S-LCA & LCC \\
\hline 1 & Climate Change & Fair Wages & Production Costs \\
\hline$(1+) 2$ & $\begin{array}{c}\text { Ozone depletion } \\
\text { Eutrophication Photochem. } \\
\text { oxidant formation }\end{array}$ & $\begin{array}{c}\text { Health (Human toxicity) } \\
\text { Working conditions }\end{array}$ & Consumer costs \\
& Acidification Particulate matter & Ionizing radiation & \\
& Ecotoxicity & Land use & \\
$(1+2+) 3$ & Water footprint & Education & \\
& Resource depletion & Human rights & \\
& (Workplace) Safety & \\
\hline
\end{tabular}

Appendix A.3. Review Analysis 
Table A3. Review analysis.

\begin{tabular}{|c|c|c|c|c|c|c|c|c|c|c|c|c|c|}
\hline & $\begin{array}{l}\text { Amini Toosi } \\
\text { et al. }\end{array}$ & $\begin{array}{l}\text { Dinh, Dinh \& } \\
\text { Götze }\end{array}$ & Ek et al. & $\begin{array}{l}\text { Gbededo \& } \\
\text { Liyanage }\end{array}$ & $\begin{array}{c}\text { Gbededo, } \\
\text { Liyanage, \& } \\
\text { Garza-Reyes }\end{array}$ & Goh et al. & $\begin{array}{l}\text { Hamdar, Chehab } \\
\text { \& S rour }\end{array}$ & Llatas et al. & $\begin{array}{c}\begin{array}{c}\text { Llatas, } \\
\text { Soust-Verdaguer \& } \\
\text { Passer }\end{array} \\
\end{array}$ & Navarro et al. & Petit-Boix et al. & Scope, Vogel \& Guenther & Zhou et al. \\
\hline Published in & 2020 & 2020 & 2020 & 2017 & 2018 & 2020 & 2016 & 2019 & 2020 & 2020 & 2017 & 2021 & 2020 \\
\hline Focus & $\begin{array}{l}\text { LCSA and } \\
\text { energetic } \\
\text { building } \\
\text { refurbishment }\end{array}$ & $\begin{array}{l}\text { sust. development } \\
\text { in the selection of } \\
\text { building materials } \\
\text { in Vietnam }\end{array}$ & indicator selection & $\begin{array}{l}\text { approach to } \\
\text { sustainable } \\
\text { manufacturing } \\
\text { assessment }\end{array}$ & $\begin{array}{l}\text { identification of } \\
\text { gaps in both } \\
\text { practice and } \\
\text { research in the field } \\
\text { of gate-to-gate } \\
\text { manufacturing } \\
\text { assessments }\end{array}$ & $\begin{array}{l}\text { revisit and review } \\
\text { TBL in the context } \\
\text { of sustainable } \\
\text { construction }\end{array}$ & $\begin{array}{l}\text { life cycle } \\
\text { evaluation (LCE) } \\
\text { methods and their } \\
\text { development for } \\
\text { road surfaces }\end{array}$ & $\begin{array}{c}\text { identify barriers } \\
\text { and challenges of } \\
\text { LCSA in general, } \\
\text { present approach } \\
\text { of an integration } \\
\text { from BIM and } \\
\text { LCSA }\end{array}$ & $\begin{array}{l}\text { LCSA in } \\
\text { cooperation with } \\
\text { Building } \\
\text { Information } \\
\text { Modeling (BIM) }\end{array}$ & $\begin{array}{c}\text { use of } \\
\text { multi-criteria } \\
\text { decision making } \\
\text { techniques that } \\
\text { have been sued to } \\
\text { date for sustainable } \\
\text { bridge design }\end{array}$ & $\begin{array}{l}\text { urban } \\
\text { sustainability and } \\
\text { life cycle thinking }\end{array}$ & $\begin{array}{l}\text { LCSA of maintenance } \\
\text { strategies using concrete } \\
\text { or cement-based } \\
\text { composites }\end{array}$ & $\begin{array}{l}\text { sustainability in } \\
\text { civil engineering }\end{array}$ \\
\hline Years & up to 2019 & - & - & $2006-2015$ & 2006-2015 & 1980-2018 & - & - & - & 1990 to 2020 & 2015-2016 & 2017 and 2020 & 2015-2019 \\
\hline Databases & $\begin{array}{l}\text { ScienceDirect, } \\
\text { Scopus }\end{array}$ & - & $\begin{array}{l}\text { Swedish Institute } \\
\text { for Standards (SIS), } \\
\text { Google Scholar }\end{array}$ & $\begin{array}{l}\text { Web of Science } \\
\text { (WOS), } \\
\text { theUniversity } \\
\text { Library Catalogue, } \\
\text { ScienceDirect, and } \\
\text { GoogleScolar }\end{array}$ & $\begin{array}{l}\text { World of Science } \\
\text { (WoS), the } \\
\text { University Library } \\
\text { Catalogue, Science } \\
\text { Direct, and Google } \\
\text { Scholar }\end{array}$ & $\begin{array}{l}\text { EBSCOhost, } \\
\text { Scopus, } \\
\text { WebofScience }\end{array}$ & - & - & Scopus & Scopus & $\begin{array}{l}\text { Google Scholar, } \\
\text { Web of Science }\end{array}$ & 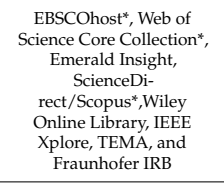 & $\begin{array}{l}\text { Web of science } \\
\text { (WoS) }\end{array}$ \\
\hline $\begin{array}{l}\text { LCSA as search } \\
\text { term included }\end{array}$ & no & - & yes & yes & - & no & no & - & yes & no & - & no & no \\
\hline $\begin{array}{c}\text { Main search } \\
\text { strategy }\end{array}$ & $\begin{array}{l}\text { all three pillars } \\
\text { were searched } \\
\text { separately }\end{array}$ & - & 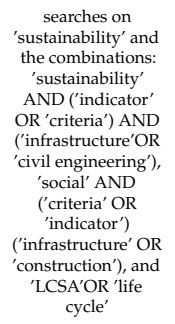 & $\begin{array}{l}\text { Sustainab"', } \\
\text { individual pillars, } \\
\text { 'LCSA', } \\
\text { 'Sustainable } \\
\text { Product } \\
\text { Develoment', } \\
\text { 'Green house Gas', } \\
\text { 'Gnergy modelling', } \\
\text { 'CSR' (Figure } 1 \text { in' } \\
\text { article) }\end{array}$ & $\begin{array}{c}\text { sustainable } \\
\text { manufacturing }\end{array}$ & $\begin{array}{l}\text { 'triple bottom line', } \\
\text { 'sustainabt' and } \\
\text { 'construction' in } \\
\text { title, abstract or } \\
\text { keywords }\end{array}$ & 'LCE' & - & 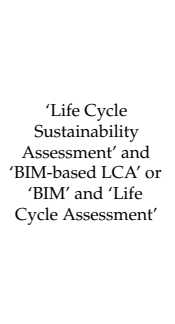 & 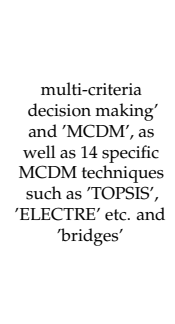 & $\begin{array}{l}\text { building sector in } \\
\text { total, but alaso food, } \\
\text { areen space, } \\
\text { landscappe, waste } \\
\text { and mobility }\end{array}$ & $\begin{array}{l}\text { focus on materials } \\
\text { (concrete, cement, } \\
\text { reinforced concrete), } \\
\text { measures (e.g. retrofit, } \\
\text { repair, maintenance) and } \\
\text { sustainability assesment } \\
\text { (e.g.g. assesssment, analy"y) }\end{array}$ & $\begin{array}{l}\text { all three pillars } \\
\text { were searched } \\
\text { separately and } \\
\text { 'civil engineering', } \\
\text { 'brige,', roaded', } \\
\text { 'highway' etc. and } \\
\text { 'sustainability' }\end{array}$ \\
\hline $\begin{array}{l}\text { Total number } \\
\text { of papers } \\
\text { considered }\end{array}$ & 101 & & - & & - & 639 & - & - & 17 & 157 & 151 & - & 1846 \\
\hline $\begin{array}{c}\text { Articles } \\
\text { considered as } \\
\text { relevant }\end{array}$ & 35 & - & - & 54 & 54 & 86 & - & - & 9 & 62 & 24 & 71 & - \\
\hline Main outcome & $\begin{array}{l}\text { LCA and LCC } \\
\text { well developed, } \\
\text { S-LCA not } \\
\text { widely used }\end{array}$ & $\begin{array}{l}\text { list of } 18 \\
\text { sustainability } \\
\text { criteria, LCC } \\
\text { received highest } \\
\text { importance }\end{array}$ & $\begin{array}{l}\text { core set of } \\
\text { indicators based on } \\
\text { requirements and } \\
\text { standards }\end{array}$ & $\begin{array}{l}\text { most approaches } \\
\text { lack a holistic view, } \\
\text { and LCSA is stillat } \\
\text { an immature stage }\end{array}$ & $\begin{array}{l}\text { LCSA is still at an } \\
\text { immature stage }\end{array}$ & $\begin{array}{l}\text { still a knowledge } \\
\text { deficit when it } \\
\text { comes to defining } \\
\text { sustainability }\end{array}$ & $\begin{array}{l}\text { complex process to } \\
\text { compare different } \\
\text { impact categories } \\
\text { and consider } \\
\text { different entities }\end{array}$ & - & $\begin{array}{l}\text { LCSA application } \\
\text { in the construction } \\
\text { sector is still } \\
\text { inadequate }\end{array}$ & - & $\begin{array}{l}\text { only two studies } \\
\text { reviewed used the } \\
\text { LCSA approach, } \\
\text { lack of social } \\
\text { studies }\end{array}$ & $\begin{array}{l}\text { global warming and } \\
\text { energy consumption cited } \\
\text { most frequently, external } \\
\text { costs, if includuded in the } \\
\text { assessment, rive the } \\
\text { sereall conomic } \\
\text { assessment, LCSA used } \\
\text { only in three cases }\end{array}$ & $\begin{array}{l}\text { existing research } \\
\text { focuses mainly on } \\
\text { the environimental } \\
\text { dimension of } \\
\text { sutsainability, lack } \\
\text { of attention to the } \\
\text { economic and } \\
\text { social dimension }\end{array}$ \\
\hline $\begin{array}{l}\text { Challenges } \\
\text { identified }\end{array}$ & $\begin{array}{l}\text { different } \\
\text { definitions of } \\
\text { functional units, } \\
\text { unequal system } \\
\text { boundaries and } \\
\text { life span of } \\
\text { buildings }\end{array}$ & $\begin{array}{c}\text { architects and } \\
\text { designers often } \\
\text { focus on the } \\
\text { economic criteria, } \\
\text { while } \\
\text { environmental } \\
\text { aspects and social } \\
\text { aspects are } \\
\text { underestimated }\end{array}$ & $\begin{array}{l}\text { current standards } \\
\text { donot trovide } \\
\text { guidanceon } \\
\text { aggereacionon of } \\
\text { indicators }\end{array}$ & $\begin{array}{l}\text { complexity, time } \\
\text { required to collect } \\
\text { a inventory of a } \\
\text { product life cycle }\end{array}$ & $\begin{array}{c}\text { difficult capturing } \\
\text { the social aspects } \\
\text { in an integrated } \\
\text { performanceassess- } \\
\text { ment }\end{array}$ & $\begin{array}{l}\text { knowledged deficit } \\
\text { when itcomes to } \\
\text { defining to } \\
\text { sustainability, } \\
\text { difficulty } \\
\text { integrating an } \\
\text { envirionmental } \\
\text { perspective into } \\
\text { national policy in } \\
\text { poverty-prone } \\
\text { regions }\end{array}$ & $\begin{array}{l}\text { lack of unanimity } \\
\text { when it comest to } \\
\text { its application lack } \\
\text { of consenssus } \\
\text { regarding gala and } \\
\text { scope, system } \\
\text { boundaries and } \\
\text { functional units }\end{array}$ & $\begin{array}{l}\text { lack of available } \\
\text { S-LCA; } \\
\text { Communication of } \\
\text { results }\end{array}$ & $\begin{array}{l}\text { harmonization of } \\
\text { the three pillars } \\
\text { and data sources as } \\
\text { main problem }\end{array}$ & - & S-LCA challenging & $\begin{array}{l}\text { wide range of } \\
\text { methodological choices; } \\
\text { harmonisationefforts }\end{array}$ & - \\
\hline
\end{tabular}


Table A3. Cont.

\begin{tabular}{|c|c|c|c|c|c|c|c|c|c|c|c|c|c|}
\hline & $\begin{array}{c}\text { Amini Toosi } \\
\text { et al. }\end{array}$ & $\begin{array}{c}\text { Dinh, Dinh \& } \\
\text { Götze }\end{array}$ & Ek et al. & $\begin{array}{l}\text { Gbededo \& } \\
\text { Liyanage }\end{array}$ & $\begin{array}{l}\text { Gbededo, } \\
\text { Liyanage, \& } \\
\text { Garza-Reyes }\end{array}$ & Goh et al. & $\begin{array}{c}\text { Hamdar, Chehab } \\
\& \& \text { Srour }\end{array}$ & Llatas et al. & $\begin{array}{c}\text { Llatas, } \\
\text { Soust-Verdaguer \& } \\
\text { Passer }\end{array}$ & Navarro et al. & Petit-Boix et al. & Scope, Vogel \& Guenther & Zhou et al. \\
\hline $\begin{array}{l}\text { Future research } \\
\text { named }\end{array}$ & $\begin{array}{l}\text { LCSA as an } \\
\text { issue that } \\
\text { should be } \\
\text { investigated } \\
\text { and considered } \\
\text { more } \\
\text { mintensively }\end{array}$ & $\begin{array}{l}\text { broadening the } \\
\text { analysis to include } \\
\text { the opinions of } \\
\text { sponsors etc. on } \\
\text { integrating } \\
\text { sustainability } \\
\text { criteriai in material } \\
\text { selection, } \\
\text { developing a } \\
\text { comprehensive } \\
\text { methodof of } \\
\text { evaluating } \\
\text { different material } \\
\text { alternatives } \\
\text { concerning the } \\
\text { three pillars as well } \\
\text { as their importance } \\
\text { weightings }\end{array}$ & $\begin{array}{l}\text { normalization and } \\
\text { weighting factors } \\
\text { used in PEF be } \\
\text { used for } \\
\text { aggregation of } \\
\text { environgental and } \\
\text { social indicators, as } \\
\text { they have been } \\
\text { agreed upon in a } \\
\text { large European } \\
\text { collaboration }\end{array}$ & 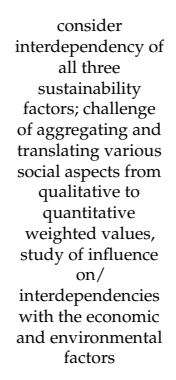 & $\begin{array}{l}\text { influence of one } \\
\text { sustainability } \\
\text { dimension on the } \\
\text { other; challenge of } \\
\text { aggrgegating and } \\
\text { translating various } \\
\text { social aspects }\end{array}$ & $\begin{array}{l}\text { expected that } \\
\text { awareness and } \\
\text { acceptance of TBL } \\
\text { will continue to } \\
\text { increase }\end{array}$ & $\begin{array}{c}\text { simplify analysis of } \\
\text { the results } \\
\text { obtained to ollow } \\
\text { for a reliable } \\
\text { comparison of } \\
\text { different } \\
\text { alternatives }\end{array}$ & - & $\begin{array}{l}\text { proposal of how to } \\
\text { apply LCSA and } \\
\text { integrate it in a } \\
\text { BIM model }\end{array}$ & - & $\begin{array}{c}\text { more } \\
\text { methodological } \\
\text { advancements are } \\
\text { needed }\end{array}$ & $\begin{array}{l}\text { more intensive dialogue } \\
\text { between stakeholders in } \\
\text { the early stagess; } \\
\text { integration of essential } \\
\text { traits of good practices in } \\
\text { reporting templates and } \\
\text { future regulation }\end{array}$ & $\begin{array}{l}\text { how to establish an } \\
\text { automatic } \\
\text { identification } \\
\text { technology of civil } \\
\text { engineering } \\
\text { sustainability } \\
\text { research based on } \\
\text { articial } \\
\text { intelligence } \\
\text { methods }\end{array}$ \\
\hline
\end{tabular}




\section{References}

1. Zanghelini, G.M.; Cherubini, E.; Soares, S.R. How Multi-Criteria Decision Analysis (MCDA) is aiding Life Cycle Assessment (LCA) in results interpretation. J. Clean. Prod. 2018, 172, 609-622. [CrossRef]

2. European Commission. EU Energy-Intensive Industries' 2050 Masterplan Becoming Climate-Neutral While Staying Competitive. 2019. Available online: https:/ / ec.europa.eu/docsroom/documents/38402 (accessed on 6 July 2020).

3. The 10YFP Secretariat. The 10 Year Framework of Programmes on Sustainable Consumption and Production Patterns (10YFP). Interim Progress Report Prepared by the 10YFP Secretariat on Behalf of the 10YFP Board for the High-Level Political Forum. 2012. Available online: https:// sustainabledevelopment.un.org/content/documents/1444HLPF_10YFP2.pdf (accessed on 17 July 2021).

4. Onat, N.C.; Kucukvar, M.; Tatari, O. Integrating triple bottom line input-output analysis into life cycle sustainability assessment framework: The case for US buildings. Int. J. Life Cycle Assess. 2014, 19, 1488-1505. [CrossRef]

5. Dong, Y.H.; Ng, S.T. A modeling framework to evaluate sustainability of building construction based on LCSA. Int. J. Life Cycle Assess. 2016, 21, 555-568. [CrossRef]

6. Akhanova, G.; Nadeem, A.; Kim, J.R.; Azhar, S. A multi-criteria decision-making framework for building sustainability assessment in Kazakhstan. Sustain. Cities Soc. 2020, 52, 101842. [CrossRef]

7. Choi, J.H. Strategy for reducing carbon dioxide emissions from maintenance and rehabilitation of highway pavement. J. Clean. Prod. 2019, 209, 88-100. [CrossRef]

8. Backes, J.G.; Suer, J.; Pauliks, N.; Neugebauer, S.; Traverso, M. Life cycle assessment of an integrated steel mill using primary manufacturing data: Actual environmental profile. Sustainability 2021, 13, 3443. [CrossRef]

9. Ding, T.; Xiao, J.; Tam, V.W.Y. A closed-loop life cycle assessment of recycled aggregate concrete utilization in China. Waste Manag. 2016, 56, 367-375. [CrossRef] [PubMed]

10. Sameer, H.; Bringezu, S. Life cycle input indicators of material resource use for enhancing sustainability assessment schemes of buildings. J. Build. Eng. 2019, 21, 230-242. [CrossRef]

11. Arroyo, P.; Fuenzalida, C.; Albert, A.; Hallowell, M.R. Collaborating in decision making of sustainable building design: An experimental study comparing CBA and WRC methods. Energy Build. 2016, 128, 132-142. [CrossRef]

12. Zamagni, A.; Pesonen, H.L.; Swarr, T. From LCA to Life Cycle Sustainability Assessment: Concept, practice and future directions. Int. J. Life Cycle Assess. 2013, 18, 1637-1641. [CrossRef]

13. Finkbeiner, M.; Schau, E.M.; Lehmann, A.; Traverso, M. Towards life cycle sustainability assessment. Sustainability 2010, 2, 3309-3322. [CrossRef]

14. Kloepffer, W. Life cycle sustainability assessment of products (with Comments by Helias A. Udo de Haes, p. 95). Int. J. Life Cycle Assess. 2008, 13, 89-95. [CrossRef]

15. Traverso, M.; Asdrubali, F.; Francia, A.; Finkbeiner, M. Towards life cycle sustainability assessment: An implementation to photovoltaic modules. Int. J. Life Cycle Assess. 2012, 17, 1068-1079. [CrossRef]

16. Cooper, H.M. Scientific Guidelines for Conducting Integrative Research Reviews. Rev. Educ. Res. 1982, 52, 291-302. [CrossRef]

17. Fink, A. Conducting Research Literature Reviews, 5th ed.; SAGE Publications: Thousand Oaks, CA, USA, 2019.

18. Öko-Institut e.V. Nachhaltige Produktentwicklung mit Ökobilanzen und Product Carbon Footprints. 2021. Available online: https: //www.oeko.de/forschung-beratung/themen/konsum-und-unternehmen/produktentwicklung-mit-oekobilanzen/ (accessed on 22 March 2021).

19. Benoît, C.; Norris, G.A.; Valdivia, S.; Ciroth, A.; Moberg, A.; Bos, U.; Prakash, S.; Ugaya, C.; Beck, T. The guidelines for social life cycle assessment of products: Just in time! Int. J. Life Cycle Assess. 2010, 15, 156-163. [CrossRef]

20. UNEP. Guidelines for Social Life Cycle Assessment of Product, 2009. Available online: https://www.lifecycleinitiative.org/wpcontent/uploads/2012/12/2009\%20-\%20Guidelines\%20for\%20sLCA\%20-\%20EN.pdf (accessed on 17 July 2021).

21. UNEP. Towards a Life Cycle Sustainability Assessment; 2011. Available online: https://www.lifecycleinitiative.org/wp-content/ uploads/2012/12/2011\%20-\%20Towards\%20LCSA.pdf (accessed on 17 July 2021).

22. Guinée, J.B. Life Cycle Sustainability Assessment: What Is It and What Are Its Challenges? In Taking Stock of Industrial Ecology; Clift, R., Druckman, A., Eds.; Springer: Cham, Switzerland, 2015; pp. 1-362. [CrossRef]

23. ISO 14040. Environmental Management-Life Cycle Assessment-Principles and Framework; 2006. Available online: https: / / www.iso.org/standard/37456.html (accessed on 17 July 2021).

24. SETAC. Environmental Life Cycle Costing: A Code of Practice; SETAC: Pensacola, FL, USA, 2011.

25. UNEP. Guidelines for Social Life Cycle Assessment of Products. Management 2020, 15, 104.

26. Guinée, J.B.; Heijungs, R.; Huppes, G.; Zamagni, A.; Masoni, P.; Buonamici, R.; Ekvall, T.; Rydberg, T. Life cycle assessment: Past, present, and future. Environ. Sci. Technol. 2011, 45, 90-96. [CrossRef]

27. Heijungs, R.; Huppes, G.; Guinée, J.B. Life cycle assessment and sustainability analysis of products, materials and technologies. Toward a scientific framework for sustainability life cycle analysis. Polym. Degrad. Stab. 2010, 95, 422-428. [CrossRef]

28. Neugebauer, S.; Martinez-Blanco, J.; Scheumann, R.; Finkbeiner, M. Enhancing the practical implementation of life cycle sustainability assessment-Proposal of a Tiered approach. J. Clean. Prod. 2015, 102, 165-176. [CrossRef] 
29. Traverso, M.; Finkbeiner, M.; Jørgensen, A.; Schneider, L. Life Cycle Sustainability Dashboard. J. Ind. Ecol. 2012, 16, 680-688. [CrossRef]

30. Corona, B.; San Miguel, G. Life cycle sustainability analysis applied to an innovative configuration of concentrated solar power. Int. J. Life Cycle Assess. 2019, 24, 1444-1460. [CrossRef]

31. MSCI. Esg Ratings Methodology; 2015. Available online: https://www.msci.com/documents/1296102/15388113/MSCI+ESG+ Fund+Ratings+Exec+Summary+Methodology.pdf (accessed on 17 July 2021).

32. REFINITIV. We Are Refinitiv. 2021. Available online: https://www.refinitiv.com/en/about-us\#sustainability (accessed on 17 July 2021).

33. EcoPortal. EcoPortal. 2021. Available online: https://www.ecoportal.com/ (accessed on 17 July 2021).

34. EcoPlatform. EcoPlatform. 2021. Available online: https://www.eco-platform.org/the-mission.html (accessed on 17 July 2021).

35. BMI. ÖKOBAUDAT. 2021. Available online: https:/ / www.oekobaudat.de/ (accessed on 17 July 2021).

36. CML-Department of Industrial Ecology. CML-IA Characterisation Factors. 2016. Available online: https://www. universiteitleiden.nl/en/research/research-output/science/cml-ia-characterisation-factors (accessed on 17 July 2021).

37. ISO 15686-5. International Standard ISO 15686-5. Buildings and Constructed Assets-Sercive Life Planning. Part 5: Life-Cycle Costing; 2017. Available online: https:/ / www.iso.org/standard/61148.html (accessed on 17 July 2021).

38. DIN EN 15804. Nachhaltigkeit von Bauwerken-Umweltproduktdeklarationen-Grundregeln für die Produktkategorie Bauprodukte; 2019. Available online: https:/ / www.beuth.de/de/norm/din-en-15804/305764795 (accessed on 17 July 2021).

39. Sherif, Y.S.; Kolarik, W.J. Life cycle costing: Concept and practice. Omega 1981, 9, 287-296. [CrossRef]

40. Hoogmartens, R.; Van Passel, S.; Van Acker, K.; Dubois, M. Bridging the gap between LCA, LCC and CBA as sustainability assessment tools. Environ. Impact. Assess. Rev. 2014, 48, 27-33. [CrossRef]

41. Toniolo, S.; Tosato, R.C.; Gambaro, F.; Ren, J. Life Cycle Thinking Tools: Life Cycle Assessment, Life Cycle Costing and Social Life Cycle Assessment; Elsevier Inc.: Amsterdam, The Netherlands, 2020. [CrossRef]

42. Miah, J.H.; Koh, S.C.L.; Stone, D. A hybridised framework combining integrated methods for environmental Life Cycle Assessment and Life Cycle Costing. J. Clean. Prod. 2017, 168, 846-866. [CrossRef]

43. Rebitzer, G.; Hunkeler, D.; Jolliet, O. LCC—The Economic Pillar of Sustainability: Methodology and Application to Wastewater Treatment. Environ. Prog. 2003, 22, 241-249. [CrossRef]

44. Hunkeler, D.; Lichtenvort, K.; Rebitzer, G. Environmental Life Cycle Costing, 1st ed.; CRC Press, Taylor \& Francis Group: Boca Raton, FL, USA, 2008.

45. Garrido, S.R. Social Life-Cycle Assessment: An Introduction; Elsevier: Amsterdam, The Netherlands, 2017; Volume 1. [CrossRef]

46. Traverso, M.; Neugebauer, S. Special Issue "Social Life Cycle Assessment-The Implementation in Different Sectors." Spec Issue. 2018. Available online: https://www.mdpi.com/journal/resources/special_issues/social_LCA (accessed on 17 July 2021).

47. BNP Paribas Real Estate. Market Focus 2020 Investmentmarkt Green Buildings Investitionsvolumen Einzeldeals und Anteil Green Buildings; 2019. Available online: https://www.realestate.bnpparibas.de/sites/default/files/document/2020-09/bnppreimmobilien-investmentmarkt-green-buildings-market-focus-2020.pdf (accessed on 17 July 2021).

48. BBSR. Bundesinstitut für Bau-, Stadt- und Raumforschung. 2021. Available online: https://www.bbsr.bund.de/BBSR/DE/ startseite/_node.html;jsessionid=F7800EB2FD66C4B38AFF410503328148.live21302 (accessed on 17 July 2021).

49. INIES. Environmental and Health Reference Data for Building. 2021. Available online: http://www.inies.fr/home/ (accessed on 17 July 2021).

50. InData. InData. 2015. Available online: https:/ / www.indata.network/about (accessed on 17 July 2021).

51. EPD. Environmental Production Declarations-International. 2021. Available online: https://www.environdec.com/all-aboutepds/the-epd (accessed on 17 July 2021).

52. EC-JRC. Product Environmental Footprint (PEF) Guide; European Commission-Joint Research Centre: Ispra, Italy, $2012 ;$ p. 154.

53. Building Research Establishment Ltd. BREEAM. 2020. Available online: https:/ / www.breeam.com/ (accessed on 29 July 2020 ).

54. U.S. Green Building Council. LEED Rating System. 2020. Available online: https://www.usgbc.org/leed (accessed on 29 July 2020).

55. DGNB. Deutsche Gesellschaft für Nachhaltiges Bauen. 2021. Available online: https://www.dgnb.de/de/ (accessed on 22 March 2021).

56. Ahmed, M.; Abul, M.; Mallick, J. World green building rating systems: A comparative study. In Proceedings of the International Conference Cum Exhibition On Building Utilities, New Delhi, India, 1-3 December 2016.

57. Elsevier. ELSEVIER Scopus. ELSEVIER. 2020. Available online: https://www.elsevier.com/de-de/solutions/scopus (accessed on 17 July 2021).

58. Amini Toosi, H.; Lavagna, M.; Leonforte, F.; Del Pero, C.; Aste, N. Life Cycle Sustainability Assessment in Building Energy Retrofitting; A Review. Sustain. Cities Soc. 2020, 60, 102248. [CrossRef]

59. Dinh, T.H.; Dinh, T.H.; Götze, U. Integration of sustainability criteria and life cycle sustainability assessment method into construction material selection in developing countries: The case of Vietnam. Int. J. Sustain. Dev. Plan. 2020, 15, 1145-1156. [CrossRef]

60. Scope, C.; Vogel, M.; Guenther, E. Greener, cheaper, or more sustainable: Reviewing sustainability assessments of maintenance strategies of concrete structures. Sustain. Prod. Consum. 2021, 26, 838-858. [CrossRef] 
61. Zhou, S.; Zhou, M.; Wang, Y.; Gao, Y.; Liu, Y.; Shi, C.; Lu, Y.; Zhou, T. Bibliometric and social network analysis of civil engineering sustainability research from 2015 to 2019. Sustainability 2020, 12, 6842. [CrossRef]

62. Zulkefli, N.S.; Rahim, F.A.; Zainon, N. Preliminary review of sustainability indicators to greening existing building based on LCSA components. Malays. Constr. Res. J. 2020, 9, 147.

63. Gbededo, M.A.; Liyanage, K.; Garza-Reyes, J.A. Towards a Life Cycle Sustainability Analysis: A systematic review of approaches to sustainable manufacturing. J. Clean. Prod. 2018, 184, 1002-1015. [CrossRef]

64. Gbededo, M.; Liyanage, K. Sustainable manufacturing assessment: Approach and the trend towards life cycle sustainability analysis. Adv. Transdiscipl. Eng. 2017, 6, 383-388. [CrossRef]

65. Goh, C.S.; Chong, H.Y.; Jack, L.; Mohd Faris, A.F. Revisiting triple bottom line within the context of sustainable construction: A systematic review. J. Clean. Prod. 2020, 252, 119884. [CrossRef]

66. Hamdar, Y.; Chehab, G.R.; Srour, I. Life-cycle evaluation of pavements: A critical review. J. Eng. Sci. Technol. Rev. 2016, 9, 12-26. [CrossRef]

67. Llatas, C.; Fornos, R.A.; Bizcocho, N.; Albalá, I.C.; Falcón, R.; Galeana, I.; García-Martínez, A.; De Cózar, J.C.G.; Alonso, S.L.; Meda, P.; et al. Towards a Life Cycle Sustainability Assessment method for the quantification and reduction of impacts of buildings life cycle. IOP Conf. Ser. Earth Environ. Sci. 2019, 323. [CrossRef]

68. Llatas, C.; Soust-Verdaguer, B.; Passer, A. Implementing Life Cycle Sustainability Assessment during design stages in Building Information Modelling: From systematic literature review to a methodological approach. Build. Env. 2020, 182, 107164. [CrossRef]

69. Navarro, I.J.; Penadés-Plà, V.; Martínez-Muñoz, D.; Rempling, R.; Yepes, V. Life cycle sustainability assessment for multi-criteria decision making in bridge design: A review. J. Civ. Eng. Manag. 2020, 26, 690-704. [CrossRef]

70. Boix, A.P.; Llorach-Massana, P.; Sanjuan-Delmás, D.; Sierra-Pérez, J.; Vinyes, E.; Gabarrell, X.; Rieradevall, J.; Sanyé-Mengual, E. Application of life cycle thinking towards sustainable cities: A review. J. Clean. Prod. 2017, 166, 939-951. [CrossRef]

71. European Commission. COP21 UN Climate Change Conference, Paris 2015. Available online: https://ec.europa.eu/commission/ priorities/energy-union-and-climate/climate-action-decarbonising-economy/cop21-un-climate-change-conference-paris_en (accessed on 18 November 2020).

72. United Nations. The 17 Goals 2015. Available online: https:/ /sdgs.un.org/goals (accessed on 18 November 2020).

73. Wiley Online Library. Special Issue:Charting the Future of Life Cycle Sustainability Assessment. 2017. Available online: https:/ / onlinelibrary.wiley.com/toc/15309290/2017/21/6 (accessed on 18 November 2020).

74. MDPI Sustainability. Special Issue "Sustainable Buildings and Energy Performance" 2020. Available online: https://www.mdpi. com/journal/sustainability/special_issues/sustainable_buildings_energy (accessed on 18 November 2020).

75. Ren, J.; Toniolo, S. Life Cycle Sustainability Assessment for Decision-Making: Methodologies and Case Studies; Elsevier: Amsterdam, The Netherlands, 2020. [CrossRef]

76. Ofori, G. Construction in developing countries: Need for new concepts. J. Constr. Dev. Ctries. 2019, 23, 1-6. [CrossRef]

77. Ioppolo, G.; Traverso, M.; Finkbeiner, M. Preface-A new paradigm for life cycle thinking: Exploring sustainability in urban development scenarios. Int. J. Life Cycle Assess. 2019, 24, 1169-1173. [CrossRef]

78. Hamed, M.; Knight, M.A.; Unger Andre, J.A. Life cycle sustainability assessment of water and wastewater infrastructure systems. Proc. Annu. Conf. Can. Soc. Civ. Eng. 2017, 2017, 337-347.

79. Hossain, K.A.; Gencturk, B. Life-Cycle Environmental Impact Assessment of Reinforced Concrete Buildings Subjected to Natural Hazards. J. Archit. Eng. 2016, 22. [CrossRef]

80. Milani, C.J.; Kripka, M. Evaluation of short span bridge projects with a focus on sustainability. Struct. Infrastruct. Eng. 2020, 16, 367-380. [CrossRef]

81. Akhtar, S.; Reza, B.; Hewage, K.; Shahriar, A.; Zargar, A.; Sadiq, R. Life cycle sustainability assessment (LCSA) for selection of sewer pipe materials. Clean. Technol. Environ. Policy 2015, 17, 973-992. [CrossRef]

82. Hossaini, N.; Hewage, K.; Sadiq, R. Spatial life cycle sustainability assessment: A conceptual framework for net-zero buildings. Clean. Technol. Environ. Policy 2015, 17, 2243-2253. [CrossRef]

83. Ostermeyer, Y.; Wallbaum, H.; Reuter, F. Multidimensional Pareto optimization as an approach for site-specific building refurbishment solutions applicable for life cycle sustainability assessment. Int. J. Life Cycle Assess. 2013, 18, 1762-1779. [CrossRef]

84. Kucukvar, M. Life Cycle Sustainability Assessment Framework For The U.S. Built Environment. Ph.D. Thesis, University of Central Florida, Orlando, FL, USA, 2013; p. 149.

85. Touceda, M.I.; Neila, F.J.; Degrez, M. Modeling socioeconomic pathways to assess sustainability: A tailored development for housing retrofit. Int. J. Life Cycle Assess. 2018, 23, 710-725. [CrossRef]

86. Hu, M.; Kleijn, R.; Bozhilova-Kisheva, K.P.; Di Maio, F. An approach to LCSA: The case of concrete recycling. Int. J. Life Cycle Assess. 2013, 18, 1793-1803. [CrossRef]

87. Bozhilova-Kisheva, K.; Olsen, S.I. Challenges in Implementing Life Cycle Sustainability Assessment ( LCSA ) and in an LCSAbased Decision-making. In Proceedings of the 6th SETAC World Congress 2012: SETAC Europe 22nd Annual Meeting, Berlin, Germany, 20-24 May 2012.

88. Gencturk, B.; Hossain, K.; Lahourpour, S. Life cycle sustainability assessment of RC buildings in seismic regions. Eng. Struct. 2016, 110, 347-362. [CrossRef] 
89. Kamali, M.; Hewage, K. Sustainability performance assessment: A life cycle based framework for modular buildings. In Proceedings of the 6th International Construction Specialty Conference (CSCE/CRC 2017), Vancouver, BC, Canada, 31 May-3 June 2017; pp. 1355-1365.

90. Balasbaneh, A.T.; Marsono, A.K.B.; Khaleghi, S.J. Sustainability choice of different hybrid timber structure for low medium cost single-story residential building: Environmental, economic and social assessment. J. Build. Eng. 2018, 20, 235-247. [CrossRef]

91. Zheng, X.; Easa, S.M.; Ji, T.; Jiang, Z. Incorporating uncertainty into life-cycle sustainability assessment of pavement alternatives. J. Clean. Prod. 2020, 264, 121466. [CrossRef]

92. Zheng, X.; Easa, S.M.; Yang, Z.; Ji, T.; Jiang, Z. Life-cycle sustainability assessment of pavement maintenance alternatives: Methodology and case study. J. Clean. Prod. 2019, 213, 659-672. [CrossRef]

93. Liu, S.; Qian, S. Towards sustainability-oriented decision making: Model development and its validation via a comparative case study on building construction methods. Sustain. Dev. 2019, 27, 860-872. [CrossRef]

94. Raymond, A.J.; Kendall, A.; DeJong, J.T.; Kavazanjian, E.; Woolley, M.A.; Martin, K.K. Life Cycle Sustainability Assessment of Fugitive Dust Control Methods. J. Constr. Eng. Manag. 2021, 147, 04020181. [CrossRef]

95. Bach, V.; Finkbeiner, M. Approach to qualify decision support maturity of new versus established impact assessment methods-demonstrated for the categories acidification and eutrophication. Int. J. LCA 2017, 22, 387-397. [CrossRef]

96. Guinée, J.B.; Lindeijer, E. Handbook on Life Cycle Assessment-Operational Guide to the ISO Standards; Springer: Dordrecht, The Netherlands, 2002. [CrossRef]

97. GreenDelta. PSILCA—Understanding Social Impacts. 2018. Available online: https://psilca.net/ (accessed on 17 July 2021).

98. Balasbaneh, A.T.; Yeoh, D.; Zainal Abidin, A.R. Life cycle sustainability assessment of window renovations in schools against noise pollution in tropical climates. J. Build. Eng. 2020, 32, 101784. [CrossRef]

99. Balasbaneh, A.T.; Marsono, A.K.B. Applying multi-criteria decision-making on alternatives for earth-retaining walls: LCA, LCC, and S-LCA. Int. J. Life Cycle Assess. 2020, 25, 2140-2153. [CrossRef]

100. Bozhilova-Kisheva, K.P.; Hu, M.M.; van Roekel, E.; Olsen, S.I. An integrated life cycle inventory for demolition processes in the context of life cycle sustainability assessment. Int. Symp. Life Cycle Assess. Constr. Civ. Eng. Build. 2012, 86, $327-335$.

101. Hossaini, N.; Reza, B.; Akhtar, S.; Sadiq, R.; Hewage, K. AHP based life cycle sustainability assessment (LCSA) framework: A case study of six storey wood frame and concrete frame buildings in Vancouver. J. Environ. Plan. Manag. 2014, 58, 1217-1241. [CrossRef]

102. Sánchez, S.; Cancio, Y.; Sánchez, I.R.; Martirena, J.F.; Rosa, E.R.; Habert, G. Sustainability assessment in Cuban cement sector- a methodological approach. IOP Conf. Ser. Earth Environ. Sci. 2019, 323. [CrossRef]

103. Berriel, S.S.; Ruiz, Y.; Sánchez, I.R.; Martirena, J.F.; Rosa, E.; Habert, G. Introducing low carbon cement in Cuba-A life cycle sustainability assessment study. In Calcined Clays for Sustainable Concrete; RILEM Bookseries; Springer: Dordrecht, The Netherlands, 2018; Volume 16, pp. 415-421. [CrossRef]

104. Settembre Blundo, D.; García-Muiña, F.E.; Pini, M.; Volpi, L.; Siligardi, C.; Ferrari, A.M. Sustainability as source of competitive advantages in mature sectors: The case of Ceramic District of Sassuolo (Italy). Smart Sustain. Built. Environ. 2019, 8, 53-79. [CrossRef]

105. Sou, W.I.; Chu, A.; Chiueh, P.T. Sustainability assessment and prioritisation of bottom ash management in Macao. Waste Manag. Res. 2016, 34, 1275-1282. [CrossRef]

106. Wang, J.J.; Wang, Y.F.; Sun, Y.W.; Tingley, D.D.; Zhang, Y.R. Life cycle sustainability assessment of fly ash concrete structures. Renew. Sustain. Energy Rev. 2017, 80, 1162-1174. [CrossRef]

107. ISO 14044. Environmental Management-Life Cycle Assessment-Requirements and Guidelines; 2018. Available online: https:/ / www.iso.org/standard/76122.html (accessed on 17 July 2021).

108. Hardi, P.; Semple, P. The dashboard of sustainability: From a metaphor to an operational set of indices. In Proceedings of the Fifth International Conference on Social Science Methodology, Cologne, Germany, 3-6 October 2000.

109. Visentin, C.; da Silva Trentin, A.W.; Braun, A.B.; Thomé, A. Life cycle sustainability assessment: A systematic literature review through the application perspective, indicators, and methodologies. J. Clean. Prod. 2020, 270, 122509. [CrossRef]

110. Ek, K.; Mathern, A.; Rempling, R.; Karlsson, M.; Brinkhoff, P.; Norin, M.; Lindberg, J.; Rosén, L. A harmonized method for automatable life cycle sustainability performance assessment and comparison of civil engineering works design concepts. IOP Conf. Ser. Earth Environ. Sci. 2020, 588. [CrossRef]

111. Wong, K.D.; Fan, Q. Building information modelling (BIM) for sustainable building design. Facilities 2013, 31, 138-157. [CrossRef]

112. Zuo, J.; Zhao, Z.Y. Green building research-current status and future agenda: A review. Renew. Sustain. Energy Rev. 2014, 30, 271-281. [CrossRef]

113. Wu, R.; Yang, D.; Chen, J. Social life cycle assessment revisited. Sustainability 2014, 6, 4200-4226. [CrossRef]

114. Montalbán-Domingo, L.; García-Segura, T.; Amalia Sanz, M.; Pellicer, E. Social Sustainability in Delivery and Procurement of Public Construction Contracts. J. Manag. Eng. 2019, 35, 04018065. [CrossRef]

115. Bork, C.A.S.; De Barba, D.J.; De Oliveira Gomes, J. Social life cycle assessment of three companies of the furniture sector. Procedia CIRP 2015, 29, 150-155. [CrossRef]

116. Hossain, M.U.; Poon, C.S.; Dong, Y.H.; Lo, I.M.C.; Cheng, J.C.P. Development of social sustainability assessment method and a comparative case study on assessing recycled construction materials. Int. J. Life Cycle Assess. 2018, 23, 1654-1674. [CrossRef]

117. Peduzzi, P. Sand, rarer than one thinks. Environ. Dev. 2014, 11, 208-218. [CrossRef] 
118. Valdivia, S.; Ugaya, C.M.L.; Hildenbrand, J.; Traverso, M.; Mazijn, B.; Sonnemann, G. A UNEP/SETAC approach towards a life cycle sustainability assessment-Our contribution to Rio+20. Int. J. Life Cycle Assess. 2013, 18, 1673-1685. [CrossRef]

119. Anand, C.K.; Amor, B. Recent developments, future challenges and new research directions in LCA of buildings: A critical review. Renew. Sustain. Energy Rev. 2017, 67, 408-416. [CrossRef]

120. Dodd, N.; Donatello, S.; Cordella, M. Level(s) - A Common EU Framework of Core Sustainability Indicators for Office and Residential Buildings. 2020, pp. 1-68. Available online: Https://SusprocJrcEcEuropaEu/Efficient_Buildings/DocumentsHtml (accessed on 17 July 2021). 